Article

\title{
Novel N4-Like Bacteriophages of Pectobacterium atrosepticum
}

\author{
Colin Buttimer ${ }^{1}$ (i), Hanne Hendrix ${ }^{2}$, Alan Lucid ${ }^{1,+}{ }^{+}$, Horst Neve ${ }^{3}$, Jean-Paul Noben ${ }^{4}$ (D), \\ Charles Franz $^{3}$, Jim O'Mahony ${ }^{1}$, Rob Lavigne ${ }^{2}$ (iD and Aidan Coffey ${ }^{1,5, * \text { (D) }}$ \\ 1 Department of Biological Sciences, Cork Institute of Technology, T12 P928 Cork, Ireland; \\ colin.buttimer@mycit.ie (C.B.); alanlucid@gmail.com (A.L.); Jim.OMahony@cit.ie (J.O.) \\ 2 Laboratory of Gene Technology, KU Leuven, 3001 Leuven, Belgium; hanne.hendrix@kuleuven.be (H.H.); \\ rob.lavigne@kuleuven.be (R.L.) \\ 3 Department of Microbiology and Biotechnology, Max Rubner-Institut, 24103 Kiel, Germany; \\ horst.neve@mri.bund.de (H.N.); charles.franz@mri.bund.de (C.F.) \\ 4 Biomedical Research Institute and Transnational University Limburg, Hasselt University, 3590 Hasselt, \\ Belgium; jeanpaul.noben@uhasselt.be \\ 5 APC Microbiome Institute, University College, T12 YT20 Cork, Ireland \\ * Correspondence: aidan.coffey@cit.ie; Tel.: +353-214-335-486 \\ + This paper is dedicated to the memory of Alan Lucid who passed away on 31 August 2017 during the \\ preparation of the manuscript.
}

Received: 15 March 2018; Accepted: 8 May 2018; Published: 14 May 2018

\begin{abstract}
Pectobacterium atrosepticum is an economically important phytopathogen that is responsible for potato blackleg and soft rot, and for which current control strategies are limited. In this study, stem samples of potato crops exhibiting blackleg were taken from three farms in Co. Cork, Ireland, and they were found to be infected with $P$. atrosepticum. Three closely related bacteriophages (phages) that are specific to this phytopathogen were isolated and characterized, namely vB_PatP_CB1, vB_PatP_CB3, and vB_PatP_CB4 (abbreviated as CB1, CB3, and CB4). Both CB1 and CB3 were determined to infect 12 strains and CB4 10 strains of the 19 strains of P. atrosepticum tested. Morphology, latent periods, burst sizes, and their stability at various temperatures and $\mathrm{pHs}$ were also examined. Genome sequencing of the three phages revealed that they shared a minimum nucleotide identity of 93\% with each other. Their genomes exhibited an Enquartavirinae genome organization, possessing several conserved proteins that were associated with phages of this group, like the type species Escherichia virus N4. Tandem electrospray ionization-mass spectrometry (ESI-MS/MS) allowed for the identification of ten structural proteins that form the virion of CB1, six that are conserved in phage N4. Biocontrol experiments demonstrated that the phages suppress soft rot formation upon co-inoculation with P. atrosepticum on whole tubers. The results of this study indicate that CB1 related phages could be good candidates for phage-based control.
\end{abstract}

Keywords: phage isolation; phage characterization; Pectobacterium; blackleg; soft rot; phage-mediated biocontrol of bacteria; plant disease biocontrol; phage therapy; N4-like phage

\section{Introduction}

The genera of Pectobacterium and Dickeya, which are often referred to collectively as the soft rot Enterobacteriaceae (SRE), are phytopathogens that cause economically important losses in a wide range of arable and ornamental crops. These bacteria are all Gram-negative, non-spore forming, facultative anaerobic rods that are typified by the production of extracellular pectinolytic enzymes during plant infection [1,2]. Both genera are considered to be among the top ten most important plant pathogens [3]. 
To date, the predominant SRE species and subspecies that cause blackleg and soft rot of the potato crop in Europe are Pectobacterium atrosepticum, Pectobacterium carotovorum subsp. carotovorum, Pectobacterium parmentieri (formally Pectobacterium wasabiae), Dickeya dianthicola, and Dickeya solani [1,4-6]. P. atrosepticum is traditionally believed to be one of the more important causative agents for blackleg in temperate climates [7], and the dominant blackleg causative agent in Scotland [5].

Strategies for the control of potato soft rot and blackleg are limited, whether they be physical, chemical, or biological. In addition, no blackleg resistant potato cultivars are available. The current approach to disease control is the use of cultivation practices to minimize levels of infection, including contamination avoidance and the removal of diseased plants and/or tissue. Seed certification schemes are also employed. However, the success of these schemes vary and are highly weather dependent $[8,9]$.

Phages, which are the viruses of bacteria, are being investigated as a potential biocontrol strategy for many problematic bacteria, including the phytopathogens. Indeed, phages of Erwinia amylovora, Xanthomonas campestris pv. vesicatoria, Agrobacterium tumefaciens, and many others have been investigated for their disease control potential $[10,11]$. In addition, a number of SRE phages have also been recently isolated and characterized [12], some of these having also been assessed for their potential as biocontrol agents of their respective phytopathogenic hosts, with promising results.

Proof of concept experiments using SRE phages on potato whole tubers have demonstrated that phage biocontrol has the capability to inhibit soft rot caused by P. carotovorum subsp. carotovorum, P. parmentieri, and D. solani [13-15]. A field trial was conducted by Adriaenssens et al. [14] using phage vB_DsoM_LIMEstone1 against $D$. solani and showed that phage treatment against blackleg resulted in decreased disease severity and improved yields. However, SRE species causing disease that were not sensitive to the phage limited the success of the overall outcome. Investigation of phage biocontrol of SRE also has not been limited to the potato. Phage biocontrol was shown, for example, to reduce the incidence of soft rot by $50 \%$ on tuber plugs of Calla lily due to P. carotovorum subsp. carotovorum infection in greenhouse trials [16]. Promising results were also demonstrated using phage against this species infecting Chinese cabbage [17].

We here report the isolation and characterization of P. atrosepticum phages vB_PatP_CB1, vB_PatP_CB3, and vB_PatP_CB4. To the authors' knowledge, this is the first report of N4-like phages to be identified infecting bacteria belonging to SRE. Escherichia phage N4 is a lytic podovirus, which was isolated in the 1960s from sewers in Genoa, Italy [18]. The phage is typified by the possession of a virion-associated RNA (vRNA) polymerase, which it injects along with its genome into its host Escherichia coli at the beginning of infection to initiate transcription of its DNA and an overall conserved transcriptional scheme [19]. To date, Genbank contains at least 56 genome sequences of N4-like phages infecting hosts belonging to the classes of Alpha-, Beta-, and Gamma-proteobacteria, with each phage genome encoding the hallmark feature of a vRNA polymerase. Six phage genera have been defined among these so far, these being G7cvirus, Lit1virus, Ea92virus, Luz7virus, and N4virus [20-23] with another two genera (Sp58virus and Dss3virus) having been proposed [21]. Furthermore, using these newly isolated N4-like phages, we demonstrated their potential for biocontrol with the suppression of soft rot formation with their co-inoculation with P. atrosepticum on potato tubers.

\section{Results}

\subsection{Isolation of SRE from Potato Crops Symptomatic of Blackleg}

In 2013, nineteen potato stem samples symptomatic for blackleg, each representing a crop, were collected from three distinct farms in Co. Cork, Ireland. Isolate identification was based on cavity formation on crystal violet pectate (CVP) medium, production of reducing substances from sucrose, acid production from $\alpha$-methyl-glucoside, Pectobacterium genus-specific along with P. atrosepticum and P. carotovorum subsp. carotovorum species-specific polymerase chain reactions (PCRs), and matrix assisted laser desorption/ionization-time of flight (MALDI-TOF) mass spectrometry. Based on these results, fourteen plants were found to be infected with P. atrosepticum with a remaining plant being 
found to be infected with both P. atrosepticum and P. carotovorum subsp. carotovorum (Supplementary Information 1, Table S1).

\subsection{Isolation of Phages, Host Range and General Characteristics}

Thirteen phage isolates were obtained from soil samples that were collected from potato grading machinery and potato fields from two of the three farms that are mentioned above. These were subjected to genomic DNA comparison. Restriction digestion analysis, employing BamHI, allowed for the identification of ten isolates that produced three similar band patterns (Figure 1). Phages producing these patterns were found in both the grading machinery and the field soils. An example of each was taken for further study, namely CB1, CB3, and CB4. These isolates produced clear plaques with an approximate diameter of $2-3 \mathrm{~mm}$ (overlay concentration $0.4 \% w / v$ agar in $\mathrm{LB}$ ) on their respective host strains of $P$. atrosepticum, with narrow halos occasionally being observed to the surrounding plaques.

The host ranges of these phages were examined using 31 bacterial strains (local Irish isolates and reference strains) from five different species belonging to SRE, namely P. atrosepticum (19 strains), P. carotovorum subsp. carotovorum (four strains), D. chrysanthemi bv. chrysanthemi (one strain), D. dianthicola (three strains), and D. solani (four strains). These phages were able to form plaques on 15 strains of their host species, P. atrosepticum, with no plaque formation or inhibition of growth being observed on strains of the other species. Slight variations in lytic ability were found among the three phages, with CB1 and CB3 determined to form plaques on 12 strains, while CB4 was only found to infect 10 of the 19 strains that were tested (Table 1).

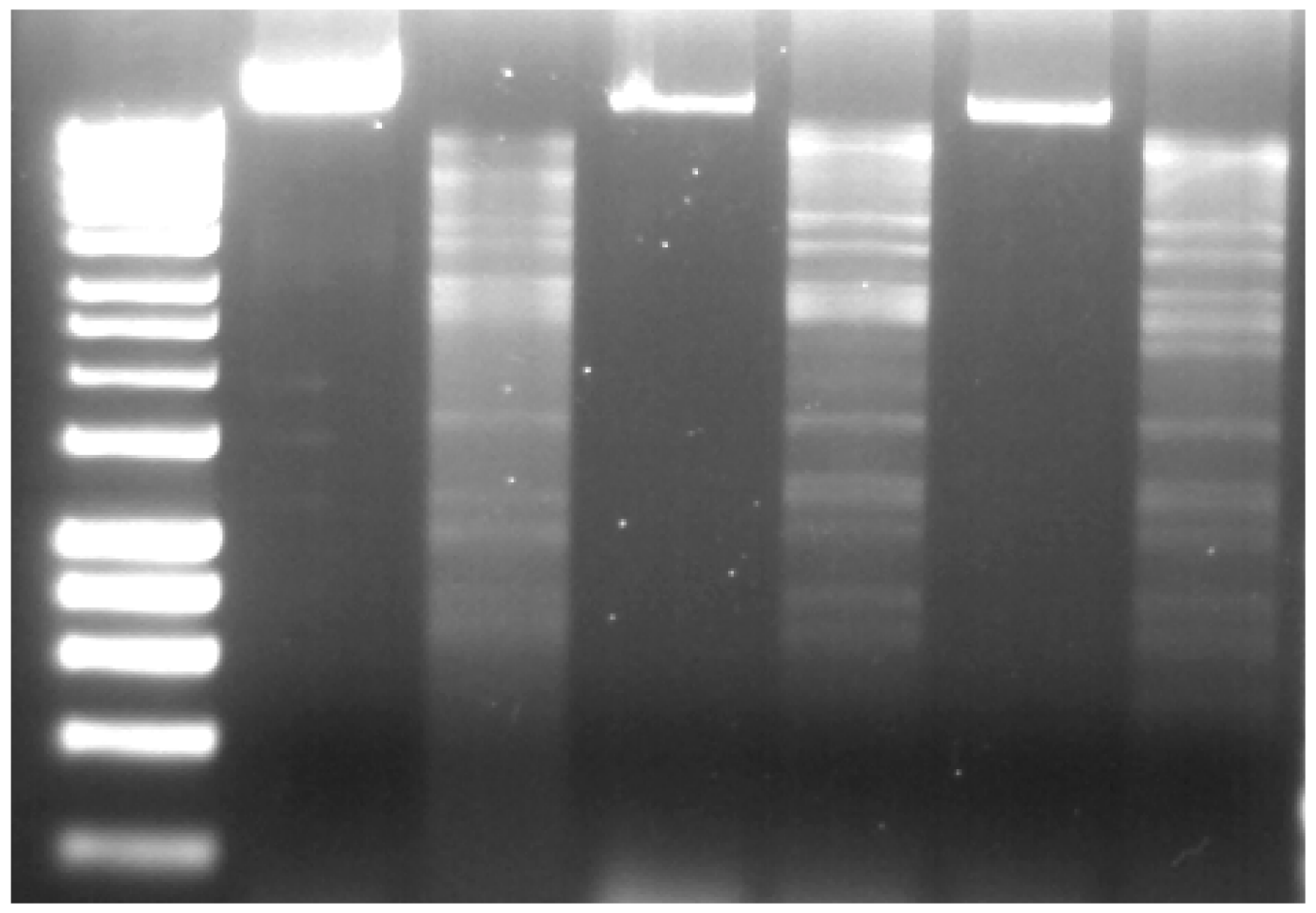

Figure 1. Genomic DNA of Pectobacterium phages CB1, CB3, and CB4, BamHI-digested (lanes 3, 5, and 7 , respectively) and undigested (lanes 2, 4, and 6, respectively). Lane 1, DNA marker (Hyperladder 1 $\mathrm{kb}$, Bioline). Gel concentration $1 \% w / v$ agarose. 
Table 1. Host range of Pectobacterium phages CB1, CB3, and CB4 on 31 strains of various members of the soft rot Enterobacteriaceae, as determined by spot testing with serial dilutions of phage suspensions. The efficiency of plating (EOP) values were determined for sensitive strains.

\begin{tabular}{|c|c|c|c|c|}
\hline \multicolumn{2}{|c|}{ Bacteria } & \multicolumn{3}{|c|}{ Bacteriophage Infection } \\
\hline Species & Strain & CB1 & CB3 & CB4 \\
\hline \multirow{19}{*}{ Pectobacterium atrosepticum } & DSMZ 18077 (type strain) & $1.000 *$ & 2.263 & 0.909 \\
\hline & DSMZ 30184 & $2.00 \times 10^{-5}$ & CS & CS \\
\hline & DSMZ 30185 & 0.371 & 0.126 & 0.136 \\
\hline & DSMZ 30186 & 0.003 & $1.000 *$ & $1.000 *$ \\
\hline & CB BL1-1 & CS & CS & CS \\
\hline & CB BL2-1 & 0.571 & 0.737 & 0.336 \\
\hline & CB BL3-1 & 0.529 & 0.605 & 0.218 \\
\hline & CB BL4-1 & 0.571 & 0.789 & 0.245 \\
\hline & CB BL5-1 & CS & 0.158 & CS \\
\hline & CB BL7-1 & CS & CS & CS \\
\hline & CB BL9-1 & 0.027 & 0.007 & 0.164 \\
\hline & CB BL11-1 & CS & 0.279 & 0.127 \\
\hline & CB BL12-2 & $2.86 \times 10^{-6}$ & 0.079 & 0.255 \\
\hline & CB BL13-1 & $1.71 \times 10^{-5}$ & 0.063 & 0.436 \\
\hline & CB BL14-1 & CS & CS & CS \\
\hline & CB BL15-1 & - & - & - \\
\hline & CB BL16-1 & 0.005 & CS & CS \\
\hline & CB BL18-1 & $\mathrm{CS}$ & 0.037 & CS \\
\hline & CB BL19-1 & 0.005 & CS & CS \\
\hline \multirow{4}{*}{$\begin{array}{l}\text { Pectobacterium carotovorum } \\
\text { subsp. carotovorum }\end{array}$} & DSMZ 30168 (type strain) & - & - & - \\
\hline & DSMZ 30169 & - & - & - \\
\hline & DSMZ 30170 & - & - & - \\
\hline & CB BL19-1-37 & - & - & - \\
\hline $\begin{array}{l}\text { Dickeya chrysanthemi } \\
\text { bv. chrysanthemi }\end{array}$ & LMG 2804 & - & - & - \\
\hline \multirow{3}{*}{ Dickeya dianthicola } & PD 482 & - & - & - \\
\hline & PD 2174 & - & - & - \\
\hline & GBBC 1538 & - & - & - \\
\hline \multirow{4}{*}{ Dickeya solani } & sp. PRI 2222 & - & - & - \\
\hline & LMG 25865 & - & - & - \\
\hline & GBBC 1502 & - & - & - \\
\hline & GBBC 1586 & - & - & - \\
\hline
\end{tabular}

Results recorded as -, no infection; CS, presence of clear spot with no plaque formation; number, EOP value; ${ }^{*}$ host strain of phage. EOP values determined by spot testing in triplicate.

Examination of the morphology of the three phages by transmission electron microscopy showed that they can be classified as members of the Podoviridae family [24]. They featured a C1 morphotype with isometric capsids (ca. $70 \mathrm{~nm}$ ) and short non-contractile tails (length: ca. $25 \mathrm{~nm}$ ) (Figure 2 and Table 2). Head and tail measurements are consistent with previously reported N4-like phages [21]. Additionally, a set of (putatively six) short whiskers (length: ca. $25 \mathrm{~nm}$ ) that were attached to a collar structure (width: ca. $19 \mathrm{~nm}$ ) were observed. At their distal ends, the whiskers terminate with elongated globular appendices (ca. $12 \mathrm{~nm} \times 7 \mathrm{~nm}$ ). The three phages were named in accordance with the nomenclature set out by Kropinski et al. [25]. 
CB1

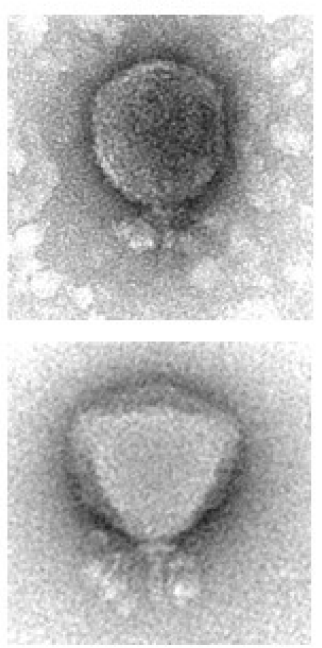

CB3
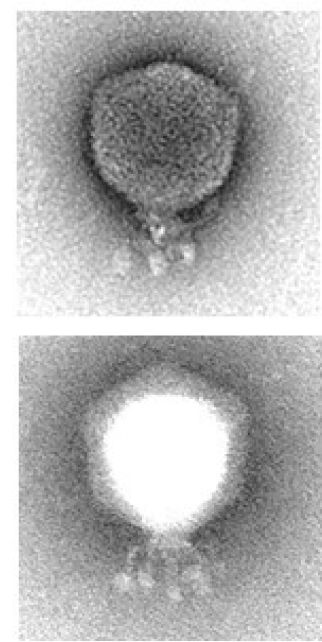

CB4

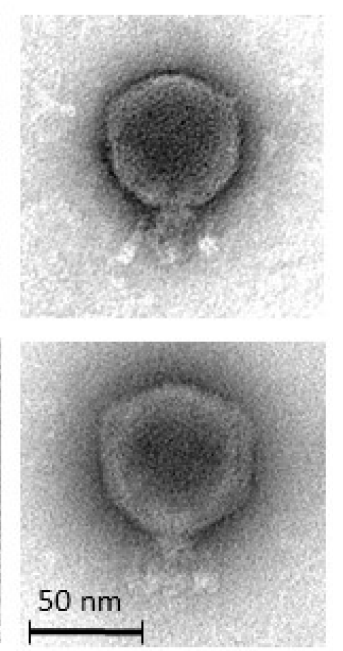

Figure 2. Transmission electron micrographs of negatively stained Pectobacterium phages CB1, CB3, and CB4 using 2\% $(w / v)$ uranyl acetate (top) and $1 \%(w / v)$ phosphotungstic acid (bottom).

Table 2. Dimensions of Pectobacterium phages CB1, CB3, and CB4 negatively stained with $2 \%(w / v)$ uranyl acetate (head sizes) or with $1 \%$ phosphotungstic acid (all other measurements).

\begin{tabular}{|c|c|c|c|c|c|c|}
\hline Phage & Head (nm) & $\begin{array}{l}\text { Tail Length } \\
\text { (nm) }\end{array}$ & $\begin{array}{c}\text { Collar } \\
\text { Width }(\mathrm{nm})\end{array}$ & $\begin{array}{l}\text { Whisker } \\
\text { Length * } \\
\text { (nm) }\end{array}$ & $\begin{array}{c}\text { Whisker } \\
\text { Ball Length } \\
\text { (nm) }\end{array}$ & $\begin{array}{c}\text { Whisker } \\
\text { Ball Width } \\
\text { (nm) }\end{array}$ \\
\hline CB1 & $\begin{array}{c}67.8 \pm 4.4 \\
(n=19)\end{array}$ & $\begin{array}{c}23.9 \pm 1.7 \\
(n=8)\end{array}$ & $\begin{array}{c}18.5 \pm 1.3 \\
(n=8)\end{array}$ & $\begin{array}{c}23.4 \pm 3.0 \\
(n=14)\end{array}$ & $\begin{array}{c}12.3 \pm 1.4 \\
(n=16)\end{array}$ & $\begin{array}{c}6.3 \pm 0.7 \\
(n=17)\end{array}$ \\
\hline CB3 & $\begin{array}{c}71.8 \pm 1.7 \\
(n=6)\end{array}$ & $\begin{array}{c}25.8 \pm 2.3 \\
(n=8)\end{array}$ & $\begin{array}{c}19.6 \pm 0.8 \\
(n=7)\end{array}$ & $\begin{array}{c}25.6 \pm 1.7 \\
(n=7)\end{array}$ & $\begin{array}{c}12.0 \pm 1.5 \\
(n=9)\end{array}$ & $\begin{array}{c}7.4 \pm 0.9 \\
(n=9)\end{array}$ \\
\hline CB4 & $\begin{array}{c}70.4 \pm 2.5 \\
(n=12)\end{array}$ & $\begin{array}{c}25.5 \pm 1.0 \\
(n=5)\end{array}$ & $\begin{array}{c}19.3 \pm 0.8 \\
(n=6)\end{array}$ & $\begin{array}{c}23.5 \pm 1.6 \\
(n=3)\end{array}$ & $\begin{array}{c}11.8 \pm 0.9 \\
(n=5)\end{array}$ & $\begin{array}{c}6.6 \pm 0.6 \\
(n=5)\end{array}$ \\
\hline
\end{tabular}

${ }^{*}$ Whisker length from collar to distal end of the whisker ball.

The one-step-growth curve assay, under standard conditions using LB medium, showed that the latent period of $\mathrm{CB} 1$ was $60 \mathrm{~min}$ with an approximate burst size of 207 plaque forming units (PFU)/cell. For CB3, a latent period of $65 \mathrm{~min}$ with an approximate burst size of $246 \mathrm{PFU} / \mathrm{cell}$ was observed. For CB4, a latent period of $65 \mathrm{~min}$ with an approximate burst size of $158 \mathrm{PFU} /$ cell observed (Supplementary Information 1, Figure S1). Phage viability under different environmental conditions was also examined. Over a duration of one hour, all of the phages were found to be stable between $-18^{\circ} \mathrm{C}$ and $50{ }^{\circ} \mathrm{C}$. They were also found to be stable between $\mathrm{pH} 5$ and $11 \mathrm{for} 24 \mathrm{~h}$ (Supplementary Information 1, Figures S2 and S3).

\subsection{Genome and Proteome Analysis}

\subsubsection{Genomes of Phages CB1, CB3, and CB4 Show an N4virus Organization}

The genome sequences obtained for phages CB1, CB3, and CB4 were 75,394 bp, 75,522 bp, and 75,973 bp with coverage of $2057 \times, 1882 \times$, and $1765 \times$, respectively. The genomes of these phages are likely linear with direct terminal repeats (DTRs) with estimated sizes of $647 \mathrm{bp}$ (for CB1 and CB3) and $648 \mathrm{bp}$ (for CB4). This estimation is based on the identification of a localized region with roughly double the read depth in comparison to average read depth across the whole genome of each phage, a similar finding to the previously reported N4-like phages [26,27]. However, it is noteworthy that termini at the ends of the DTRs for these phages can be asymmetric, as seen in the case of Escherichia 
phage N4 itself [28]. It is not known whether DTR asymmetry exists in phages CB1, CB3, and CB4. As well as this, the average GC content of these genomes was found to be $49 \%$, which was just below the GC content associated with the host bacterium P. atrosepticum at 50-51\% [29,30].

The number of predicted open reading frames $(\mathrm{ORFs})$ that is determined on the non-redundant genome of these phages were 97, 102 and 100 for CB1, CB3, and CB4, respectively (Supplementary Information 2-4). Proteins that were predicted to play roles in transcription, DNA replication, virion morphogenesis, and host lysis were identified in all three phages as well as putative genes for homing endonucleases (Figure 3). No integrase, excisionase, or repressor genes were detected, suggesting that all three phages have an exclusively lytic lifecycle. Moreover, no ORFs were identified for pathogenicity or known toxins.

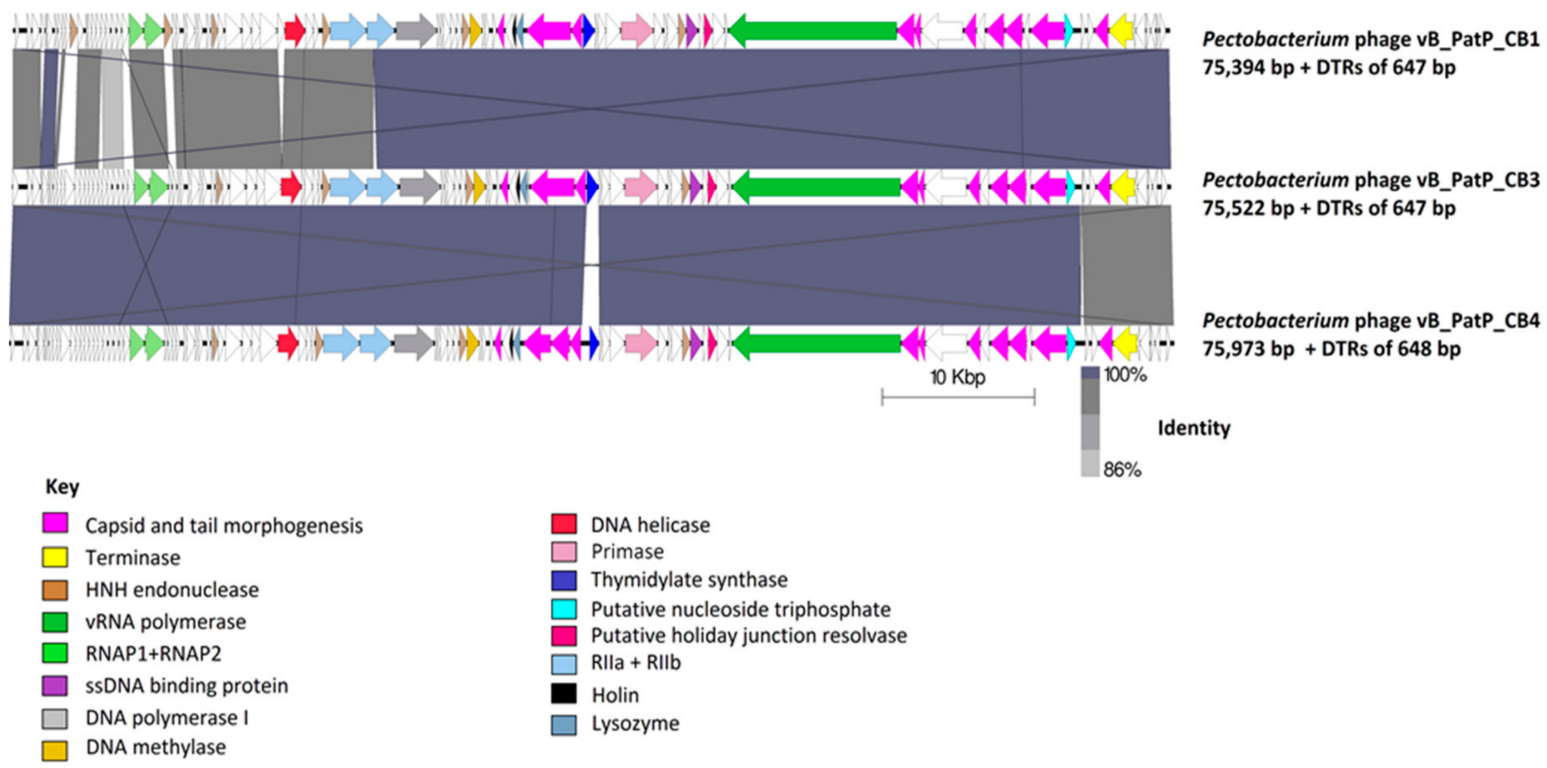

Figure 3. Comparison of the genomes of Pectobacterium phages CB1, CB3, and CB4 employing BLASTN and visualized with Easyfig. Genome maps comprise of arrows indicating the locations of open reading frames (ORFs) among the different phage genomes. Arrows have been color-coded describing their predicted roles (see key), and lines between genome maps indicate levels of homology.

Phages CB3 and CB4 exhibited a 97\% genome-wide nucleotide identity (BLASTN algorithm) and can thus be considered different isolates of the same phage species [31]. The major feature variations found between them being their ORFs for thymidylate synthase and N4 gp32-like protein. The only major difference identified with a host range between these phages was the ability of CB3 to infect two extra P. atrosepticum strains (CB BL5-1 and CB BL18-1) (Table 1). In addition, phage CB4 also possesses two genes for tRNAs (for asparagine \& glutamine). In contrast, phage CB1 was only $95 \%$ similar to CB3 and 93\% similar to CB4. This places CB1 on the boundary of speciation with the other two phages. CB1 possesses the same predicted thymidylate synthase gene and it has no tRNA genes like CB3. However, the predicted early gene region possesses variations in its ORF content not shared with CB3 and CB4. These differences include the presence of different hypothetical proteins and the presence of two additional $\mathrm{HNH}$ endonucleases. There is also notable sequence variation of the rIIB protein of CB1 to that of the other two phages. Interestingly, CB1 shares its N4 gp32-like gene with CB4 (Supplementary Information 1, Table S2).

The overall genomic architecture of the CB1-like phages resembles those that are belonging to the N4-like group (Figure 4), possessing all 18 core proteins of these phages that were identified by Li et al. [32] (Supplementary Information 1, Table S3), thus allowing the N4-like designation. When comparing these phages to Escherichia phage N4, the gene order of most structural proteins is well conserved with major variations associated with the genes that are involved in host lysis and 
the genes for structural proteins believed to play roles in tail morphogenesis. This observation has been noted among other N4-like phages [33,34]. These phages do not fall within any genera currently defined in the N4-like group to date. Phylograms that are based on the vRNA and DNA polymerase proteins show that they form their own distinct clade among these phages (Figure 5), with their closest evolutionary relationship appearing to be with the phages of the genera of Lit1virus and Luz7virus. Additionally, when protein homology was calculated with Gegenees analysis (TBLASTX), they show limited identity to other N4-like members (Figure 6).

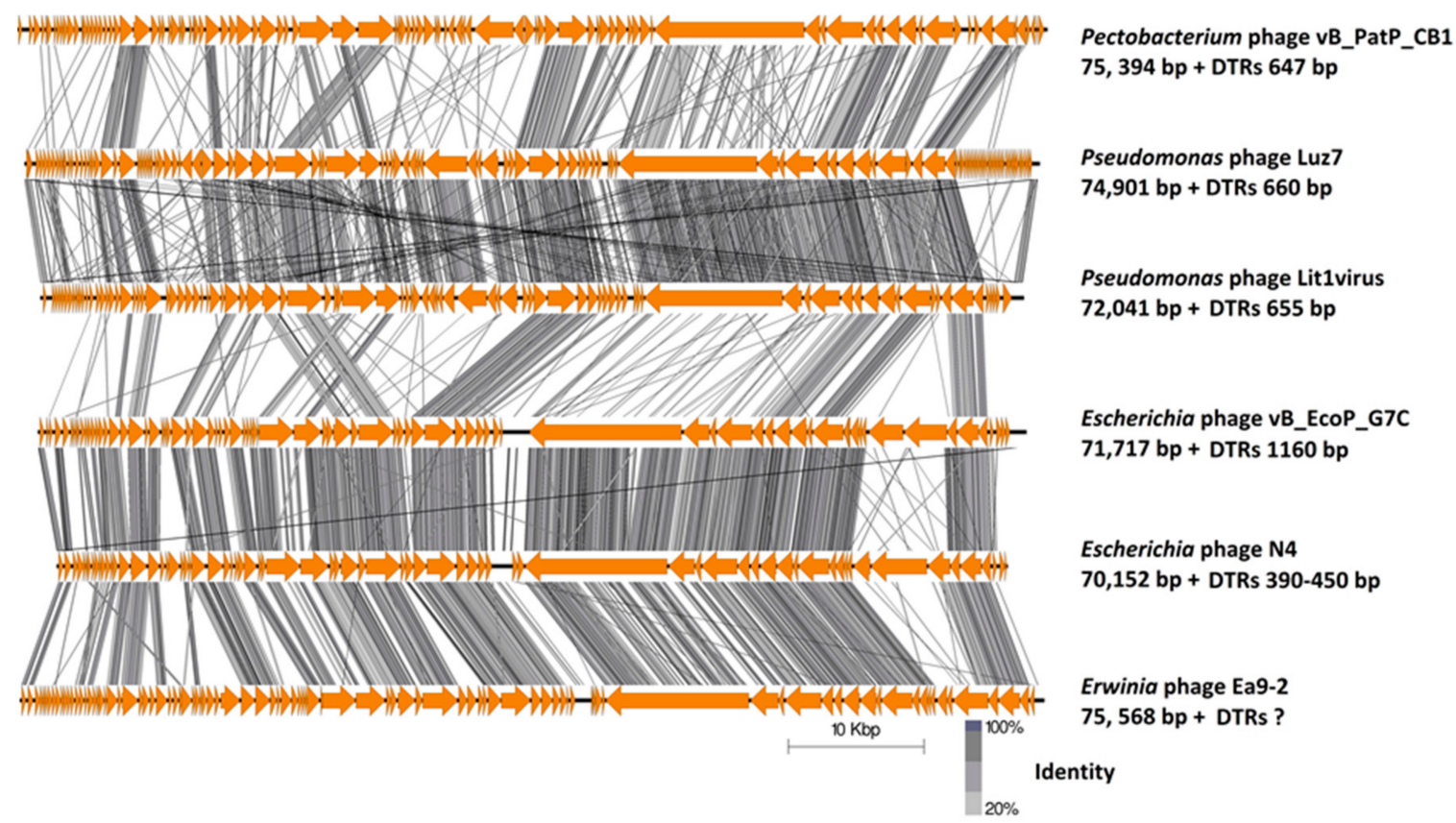

Figure 4. Comparison of the genomes of Pectobacterium phage CB1 with those phages representing the genera of N4virus, G7cvirus, Ea92virus, Lit1virus, and Luz7virus employing TBLASTX and visualized with Easyfig. Genome maps comprise of arrows indicating the locations of genes on the different phage genomes, and lines between genome maps indicate the level of homology. 


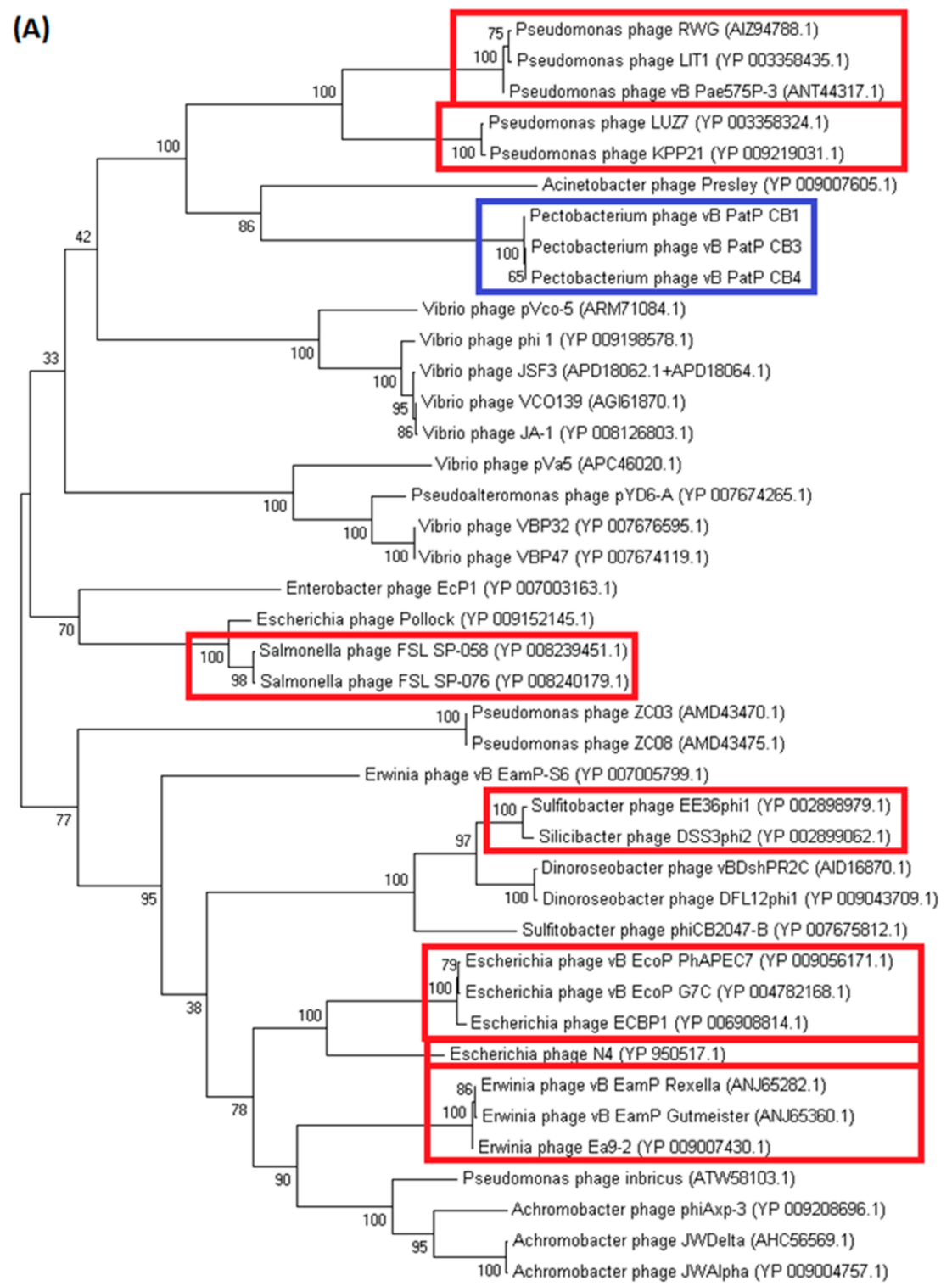

\section{Lit1virus}

Luz27virus

CB1-like phages

'Sp58virus'

'DSS3virus'

G7cvirus

\section{N4virus}

Ea93virus

Figure 5. Cont. 


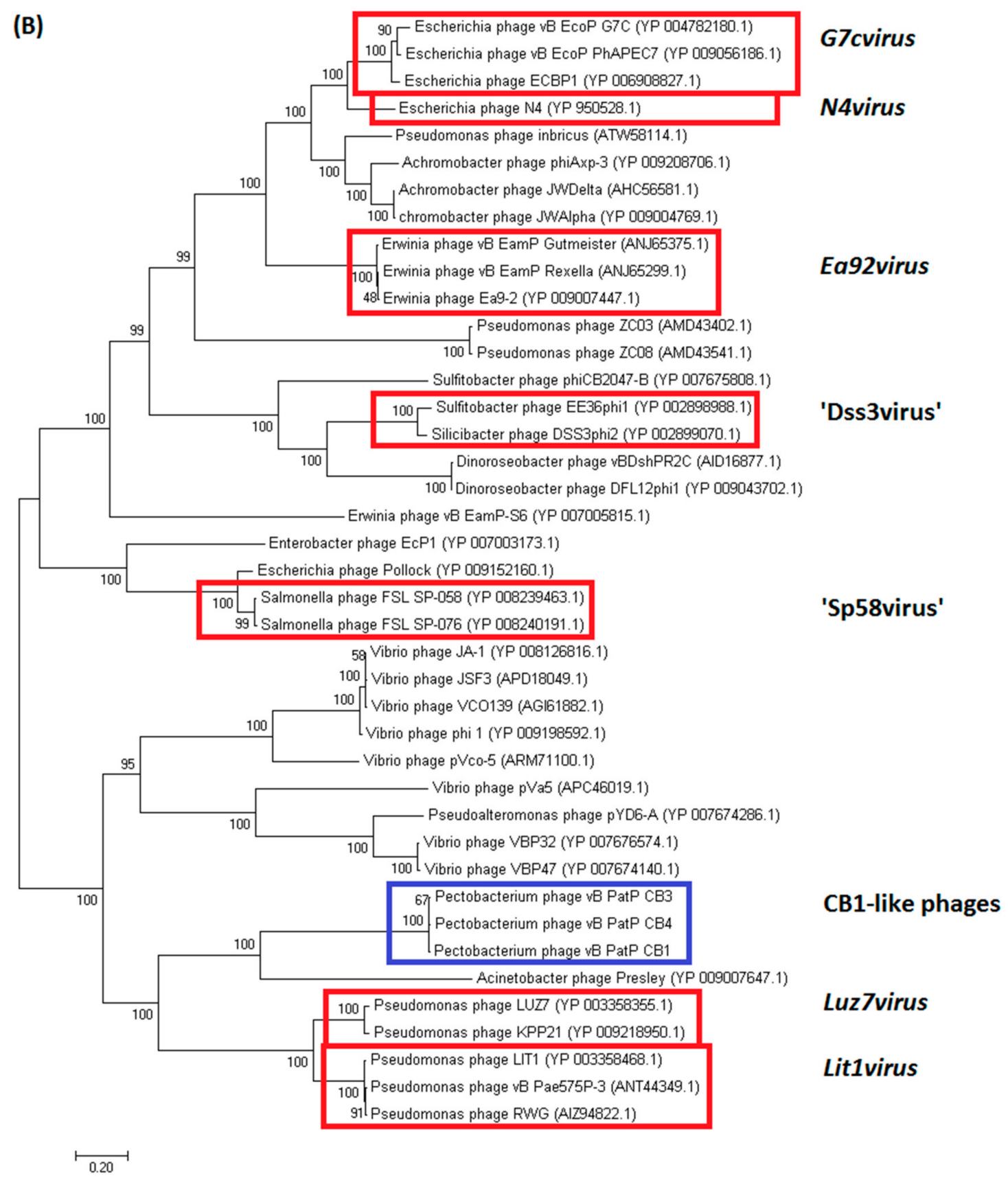

Figure 5. Phylogenetic analysis using the (A) DNA polymerase (log likelihood $=-16,535.57)$ and (B) vRNA polymerase (log likelihood $=-103,761.67)$ protein sequences of Pectobacterium phages CB1, CB3 and CB4 and 38 other N4-like phages. Phages belonging to the genera of G7cvirus, Lit1virus, Ea92virus, Luz7virus, and N4virus and proposed genera Sp58virus and Dss3virus are highlighted. The amino acid sequences were compared using MUSCLE. The tree was constructed using the maximum likelihood algorithm. The percentages of replicate trees were assessed with the bootstrap test (1000). 


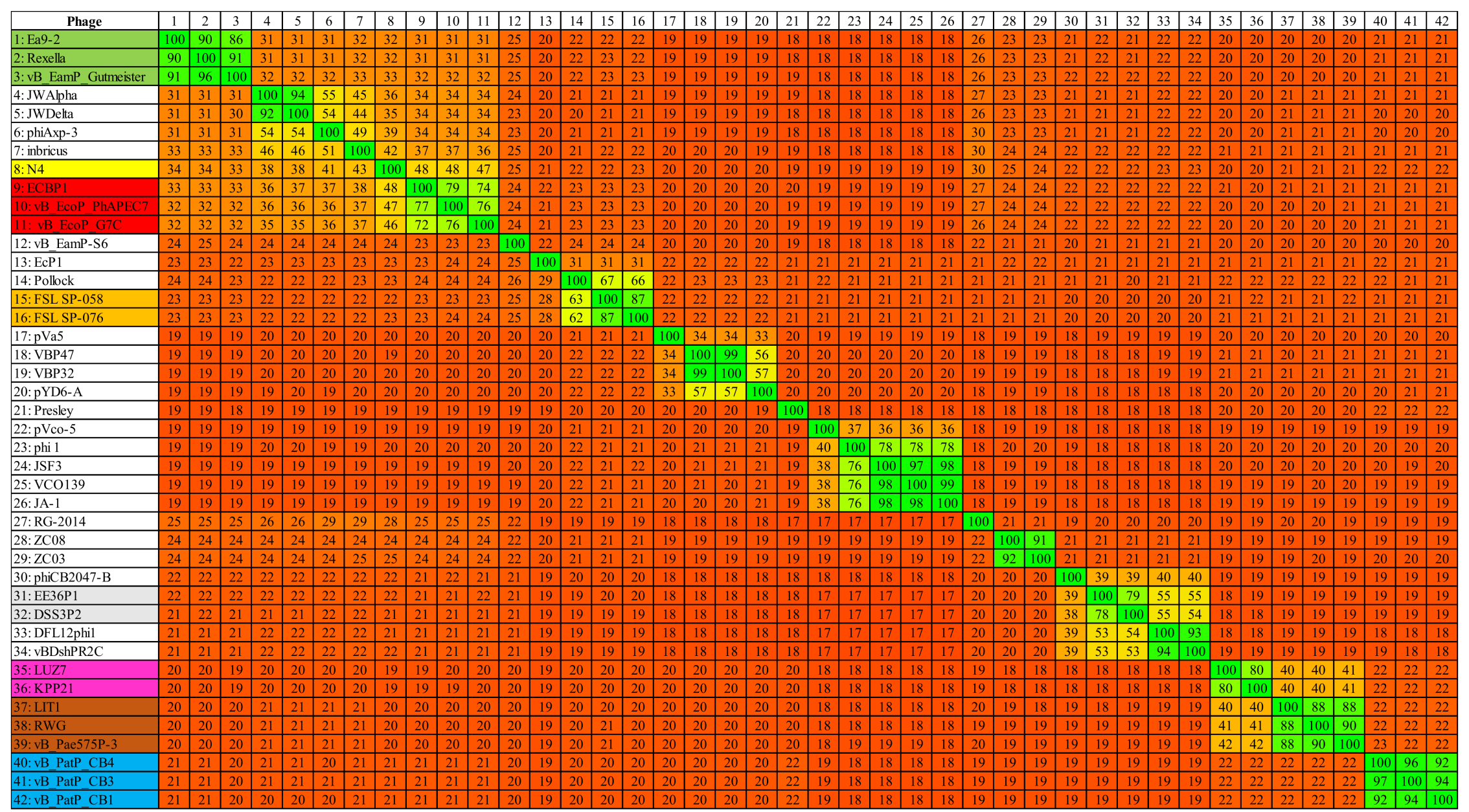

Figure 6. TBLASTX heat map generated using Gegenees with accurate parameters - fragment length: $200 \mathrm{bp}$; and step size: $100 \mathrm{bp}$; threshold: $0 \%$. The map includes the genomes of 38 N4-like phages with phages representing the genera G7cvirus (red), Lit1virus (brown), Ea92virus (green), Luz7virus (pink), and N4virus (yellow) and proposed genera Sp58virus (orange) and Dss3virus (grey), with the Pectobacterium phages CB1, CB3 and CB4 coded in blue. 


\subsubsection{Transcription}

Transcription of the CB1-like phage genomes likely happens in a similar manner to that of Escherichia phage N4. All three phages possess a vRNA (CB1_77, CB3_82, CB4_81), which conducts the transcription of single-stranded DNA that is initiated at hairpin promoters that are located within the early gene region. These promoters are composed of a five-nucleotide hairpin with a three-nucleotide loop possessing a central purine [19]. Inspection of the early gene region of phages CB1, CB3, and CB4 reveal the presence of three potential hairpin loops for all three, which appear analogous to hairpin loops in phage N4 (Supplementary Information 1, Table S4). Middle gene transcription in phage N4 is conducted by a heterodimeric RNA polymerase that is related to the T7-like RNA polymerase family [35], with the CB1-like phages also possessing homologs (CB1_22, 23, CB3_24, 25, and CB4_24, 25). Finally, late gene transcription of phage N4 involves its ssDNA-binding protein activating the E. coli sigma 70 RNA polymerase directing it towards the N4 late promoters [36], with the ssDNA-binding protein also having homologs among the CB1-like phages (CB1_72, CB3_77, and CB4_76). Within the non-redundant parts of the genomes of the CB1-like phages, 18 putative rho-independent terminators were identified for CB1 and CB3, with 17 being identified for CB4 (Supplementary Information 1, Tables S5-S7). Comparison between these phages showed that 16 of these terminators were located at similar locations among their respective genomes (Supplementary Information 1, Table S8).

\subsubsection{DNA Replication, Metabolism and Methylation}

The CB1-like phages have several components of a DNA replication system, including a DNA polymerase I (CB1_46, CB3_50, CB4_49), a helicase (CB1_40, CB3_42, CB4_42), and a primase (CB1_67, CB3_72, CB4_71). Their ability to alter the nucleotide pool of their host exploiting a thymidylate synthase (CB1_63, CB3_68, CB4_67) allows for the conversion of dUMP to dTMP and a putative nucleoside triphosphate pyrophosphohydrolase (CB1_87, CB3_92, CB4_91), which allows for the conversion of nucleoside triphosphates to their monomer form. These phages also possess a DNA adenine methylase (CB1_53, CB3_57, CB4_56) (IPR012327). Indeed, restriction digestion patterns of the genomic DNA of CB1, CB3 and CB4 using ClaI indicate that their DNA is likely deoxyadenosine-methylated (Supplementary Information 1, Figures S4-S6). Such methylation is known to occur on the DNA of a number of other phages, such as P1 and T4 of E. coli. It can have regulatory functions that are involved in phage DNA packaging and transcription, but additionally, can provide resistance against host restriction endonucleases [37].

\subsubsection{Cell Lysis}

Escherichia phage N4 possesses a signal-anchor-release (SAR) endolysin ( $N$-acetylmuramidase, pfam05838) [38]. Such endolysins are transported to the inner membrane by the host sec system and they depend on pin holins to cause the collapse of membrane potential to induce their cell wall degrading activity [39]. A typical feature of such endolysins is the possession of an N-terminal transmembrane domain. However, the CB1-like phage endolysin (Endolysin lambda type, IPR034691) (CB1_60, CB3_64, CB4_63) lacks this feature, thus indicating that their endolysin likely depends on the predicted class II holin (CB1_59, CB3_63, CB4_62) for release into the host cell periplasm to reach cell wall peptidoglycan [39]. Situated next to these predicted ORFs for the endolysin and holin of the CB1-like phages are two overlapping ORFs (CB1_58, 58a, CB3_62, 62a, CB4_61, 61a), which possess one of the typical gene arrangements of a spanin rz and rz1 pair [40]. In this spanin pair arrangement, the gene for the rz protein is the larger of the two, encoding a protein with a transmembrane domain. The smaller gene encodes a lipoprotein. However, in the CB1-like example, the ORF that is predicted to encode the lipoprotein is the larger of the two with the smaller protein lacking the predicted transmembrane domain. 


\subsubsection{Structural Proteome of Phage CB1}

There is a minimum of ten proteins that have been identified to form the virion of Escherichia phage N4 [41], with in silico analysis showing six to be shared with phage CB1. These six are the vRNA polymerase (CB1_77), the major capsid (CB1_83), the portal protein (CB1_86), and structural proteins of unknown function resembling those of gp52 (CB1_79), gp54 (CB1_81), and gp67 (CB1_90) of N4. Those that were not found to be shared with CB1 were the tail sheath (gp65), the tail appendage (gp66), the head decorating protein (gp17), and one other structural protein (gp51) that has previously been suggested to be an internal virion protein [42]. Using in silico analysis, three proteins were identified to play potential roles in the morphogenesis of the tail structure of CB1 not shared with N4, namely CB1_57, 61, and 62. The CB1_61 gene product is likely a tail spike given that it possesses an SGNH hydrolase-type esterase domain (IPR013830), suggesting enzymatic activity, like the tail spike (gp63.1) of N4-like Escherichia phage G7C, which deacetylates host surface polysaccharides [43]. Mass spectrometry (ESI-MS/MS) that was conducted on the structural proteome of CB1 verified the presence of the shared N4 structural proteins along with the three identified putative tail proteins and one hypothetical protein (CB1_78) (Table 3 and Supplementary Information 5, Table S1). This latter protein of the CB1 virion mirrors the position of gp51 of phage N4, but shares no homology. All of the CB1 structural proteins that were identified possess homologs in phages $C B 3$ and CB4, with the putative tail spike protein CB1_61 being split into two ORFs on the genome of CB4 (CB4_64, 65). Furthermore, the large terminase responsible for virion DNA packaging was identified for all three phages (CB1_91, CB3_97, CB4_95).

Table 3. Results of tandem mass spectrometry of proteins of the Pectobacterium phage CB1 virion.

\begin{tabular}{ccccc}
\hline ORF & Predicted Function & $\begin{array}{c}\text { Molecular } \\
\text { Mass (kDa) }\end{array}$ & $\begin{array}{c}\text { No. of Unique } \\
\text { Peptides }\end{array}$ & $\begin{array}{c}\text { Sequence } \\
\text { Coverage \% }\end{array}$ \\
\hline CB1_57 & Putative tail protein & 15.59 & 6 & 71 \\
CB1_61 & Putative tail spike protein & 104.98 & 19 & 29 \\
CB1_62 & Putative tail protein & 26.01 & 10 & 55 \\
CB1_77 & Virion associated RNA polymerase & 399.92 & 37 & 13 \\
CB1_78 & (N4 gp50-like) & 41.64 & 15 & 52 \\
CB1_79 & Unknown structural protein & 14.2 & 3 & 19 \\
CB1_81 & Structural protein (N4 gp52-like) & 28.82 & 9 & 53 \\
CB1_83 & Major capsid protein (N4 gp56-like) & 43.33 & 33 & 75 \\
CB1_86 & Portal protein (N4 gp59-like) & 83.31 & 27 & 45 \\
CB1_90 & Structural protein (N4 gp67-like) & 33.72 & 9 & 40 \\
\hline
\end{tabular}

\subsubsection{Selfish Genetic Elements}

Homing endonucleases are mobile genetic elements with endonuclease activity that only promote the spread of their own encoding gene [41]. Several homing endonucleases of the HNH family (IPR003615) have been identified on the genomes of the three CB1-like phages. Phage CB1 itself was found to possess six homing endonucleases (CB1_24, 33, 39, 43, 52, 71), whereas phages CB3 (CB3_36, $47,56,76)$ and CB4 $\left(C B 4 \_36,46,55,75\right)$ both possess four. Such genes have also been identified among other N4-like phages [26,34].

\subsection{Phage Biocontrol on Whole Tubers}

The phage mixture consisting of phages CB1, CB3, and CB4 was assessed for its ability to suppress soft rot (in a whole tuber assay) caused by a mixed infection by their host P. atrosepticum strains DSM 18077 and DSM 30186. The potato cultivar Rooster was selected for these experiments, given that it is the predominant variety that is grown in the Republic of Ireland (it comprised $60 \%$ of the Irish crop in 2014) [44].

The whole tuber rot assay was carried out independently in triplicate, and the results were averaged. Assay involved two sets of ten tubers that were treated with bacteria (designated sets (a) and 
(b), $100 \mu \mathrm{L}$ at approx. $1.0 \times 10^{7} \mathrm{CFU} / \mathrm{mL}$ ), which were allowed to absorb into the tuber tissue. A third set (c) was treated with water. Sets (a) and (c) were treated with SM, while (b) was treated with the phage mixture $\left(100 \mu \mathrm{L}\right.$ at $\left.1 \times 10^{7} \mathrm{PFU} / \mathrm{mL}\right)$. Following incubation, the average weight of rotten tissue from each set of tubers was recorded. Set (a) (bacteria + SM buffer) was $5.39 \pm 3.121$ g; Set (b) (bacteria + phage) was $0.311 \pm 0.498 \mathrm{~g}$, thus the average weight of infected tubers that were treated with phage was less than that treated without phage, with this result being statistically significant $(p<0.0005)$. Therefore, indicating that phage treatment limited soft rot formation. No rot was observed for set (c) (Figure 7). Look to Supplementary Information 1, Table S7 for the visual outcome of treated tuber sets (a), (b) and (c).

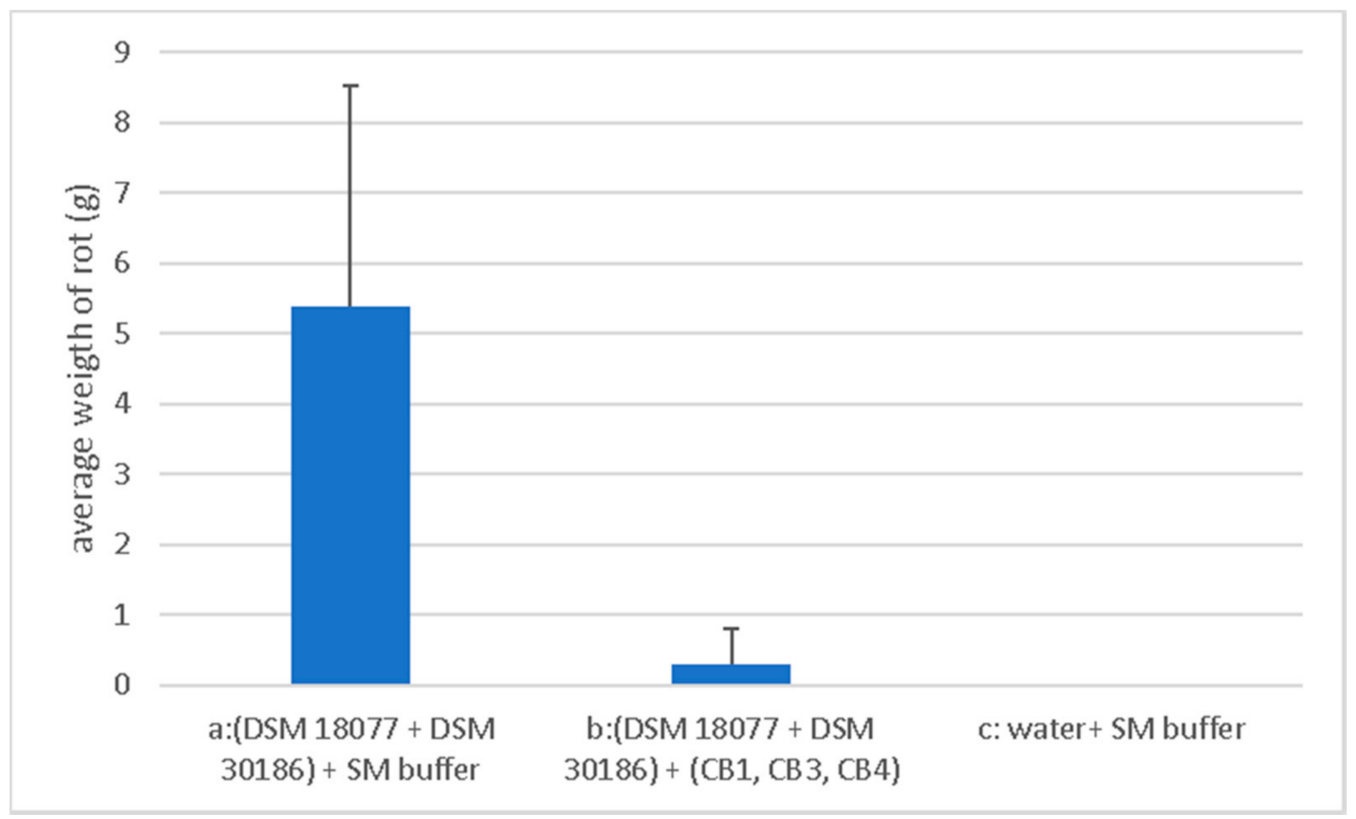

Figure 7. Protective effective effect of a phage mixture containing Pectobacterium phages CB1, CB3, and CB4 on whole tubers against a mixed infection of Pectobacterium atrosepticum strains DSM 18077 and DSM 30186. The assay $(n=10)$ was carried out independently in triplicate and results were averaged.

\section{Discussion}

Of the sixteen samples of potato crops symptomatic of blackleg that were obtained from three potato farms in Co. Cork, from which pectolytic isolates were found, fifteen were identified to be infected with $P$. atrosepticum with the remaining infection being identified to be caused by a mixture of $P$. atrosepticum with $P$. carotovorum subsp. carotovorum. This study focused on the identification and isolation of exclusively lytic phages of P. atrosepticum from the potato crop environment, followed by an assessment of their potential for biocontrol applications against soft rot and/or blackleg disease. $P$. atrosepticum is highly relevant to Irish potato horticulture, and to date, relatively few reports focusing on phage biocontrol of this pathogen have appeared in the scientific literature.

During an enrichment screening for P. atrosepticum phages, three closely related phage isolates were obtained, namely CB1, CB3, and CB4. Genome sequencing revealed them to be N4-like, sharing a similar gene order and possessing all 18 core genes that were found among all N4-like members. For phage therapy applications involving the treatment of Pseudomonas aeruginosa murine infections, N4-like phages have been deemed to be safe and effective [45]. This suggested that the three identified phages could be good candidates for biocontrol applications.

Phages CB1, CB3, and CB4 appear to possess relatively broad host ranges within their host species, collectively spanning 15 of the 19 tested P. atrosepticum strains (Table 1). By comparison, among the other members of the N4-like phages (infecting Escherichia, Pseudomonas, Vibrio, and Roseovarius), many 
have been found to propagate only on the strain used in the original isolation [34,46,47]. The relative broad host range that was observed is desirable for their use in biocontrol applications. Nevertheless, the application of these phages would have limited biocontrol potential where other SRE species may be involved in disease. Additionally, P. atrosepticum strains that were tested consisted predominantly of those from an Irish environment. It is unknown if strains from a different geographical location would have a similar susceptibility to these phages. However, resistance could be overcome by supplementing the phage mixture with additional phages targeting resistant $P$. atrosepticum strains, as well as other SRE species. The generation of phage cocktails is an important approach being adopted for phage preparations for use in the food industry and veterinary medicine as it ensures the widest possible host range against the targeted bacteria $[48,49]$. Phages with host ranges that were limited within their respective host species have been observed for a number of other studies focusing on SRE phage biocontrol $[13,14,17]$. Nevertheless, a few notable exceptions have been described, such as Dickeya phages D4 and D5 being able to infect several Dickeya species and Dickeya phages $\varphi$ PD10.3 and $\varphi$ PD23.1 being able to infect $D$. solani, P. carotovorum subsp. carotovorum and P. parmentieri [12,13]. To date, no broad host range phage infecting multiple SRE species, including P. atrosepticum, has been described.

The tuber rot assay in this study indicated that phages CB1, CB3, and CB4 appeared to possess some potential for the inhibition of soft rot formation of potato tubers (Figure 7). A similar finding was previously demonstrated using phages against $P$. carotovorum subsp. carotovorum, $D$. solani, and P. parmentieri [13-15]. An approximate multiplicity of infection (MOI) of 1 was used in our experiments to achieve this effect, lower than that reported with Dickeya phage vB_DsoM_LIMEstone1 at a MOI of 10 and 100 [14], but higher than that with Dickeya phages ФPD10.3 and ФPD23.1 against P. carotovorum subsp. carotovorum, D. solani, and P. parmentieri at an MOI of 0.01 [15]. However, further work is necessary to examine the inhibitory effect of soft rot on potato tubers by the CB1-like phages in more detail as well as additional studies to explore if the phages could inhibit blackleg formation on whole plants. Obviously, other environmental conditions that could potentially affect the viability of these phages in field applications, such as UV light, salinity, soil composition, and agrochemical factors (including fertilizers etc.) would also require investigation.

Of the ten structural proteins that were identified to form the CB1 virion (Table 3), four were not shared with that of Escherichia phage N4 (CB1_57, 61, 62, and 78). These proteins appear to be associated with tail components of the CB1 virion. Their lack of homology is likely due to their adaption to allow for the recognition of its host bacterium and enable subsequent DNA injection. For N4-like Escherichia phage G7C to recognize its host, its tail spike esterase domain must first deacetylate the O-antigen of its host lipopolysaccharide [43]. This may also be the case for the CB1-like phages with their putative tail spike (CB1_61, CB3_66, and CB4_75, 76) possessing an SGNH hydrolase-type esterase domain (IPR013830).

Phylogenetic analysis (based on phylograms and Gegenees (TBLASTX) of CB1-like phages show that they are distinct members within the N4-like group, with their closest evolutionary relationship being found with phages of the genera Lit1virus and Luz7virus. This analysis also indicates the existence of higher order taxonomic relationships between genera of the N4-like phages. Such relationships are becoming apparent due to the increasing number of N4-like genomes being added to public databases. Such a relationship was identified between the phages belonging to the genera of N4virus, G7cvirus, and Ea92virus with Achromobacter phage JWAlpha, which has been proposed to form the subfamily Enquartavirinae [21]. A similar connection was also found with the genera of Luz7virus and Lit1virus (Figures 5 and 6). These relationships are indicated with clades that are closely situated within phylograms and the sharing of protein sequence identity of $\sim 30-40 \%$ in Gegenees analysis. 


\section{Materials and Methods}

\subsection{Bacterial Strains, Phage and Cultivation Conditions}

CVP agar was used to isolate Pectobacterium strains from stems of potato plants presenting symptoms of blackleg [50]. Bacterial identification was achieved by using biochemical and physiological tests [51], genus and species-specific PCRs [52-54], and MALDI-TOF mass spectrometry (Bruker Daltonics Biotyper, Bruker, Billerica, MA, USA). To grow bacterial strains and to propagate phage Lysogeny broth (LB), LB agar $(1.5 \% w / v$ agar) and LB overlays $(0.4 \% w / v$ agar) were used. All cultures were grown at $25{ }^{\circ} \mathrm{C}$ unless stated otherwise. Phages were propagated on P. atrosepticum strains DSM 18077 (for phage CB1) and DSM 30186 (for phages CB3 and CB4).

\subsection{Phage Isolation}

Phages were isolated using an enrichment method. Five grams of soil was weighed out and were placed into $30 \mathrm{~mL}$ of LB broth, along with the addition of $300 \mu \mathrm{L}$ of an overnight culture of P. atrosepticum (DSM 18077, DSM 30184, DSM 30185, and DSM 30186) and then incubated for $18 \mathrm{~h}$ at $25{ }^{\circ} \mathrm{C}$. This was centrifuged to pellet soil matter with supernatant then being filtered $(0.45 \mu \mathrm{m}$ pore-size filter, Sarstedt, Nümbrecht, Germany). The supernatant was spotted (10 $\mu \mathrm{L})$ onto LB overlays that were seeded with different strains of Pectobacterium. Phages were isolated by picking individual plaques and then replating and reisolating to ensure purity [55].

\subsection{Host Range and General Characterization}

Host range of phages was tested by spotting a serial dilution (neat to $10^{-7}$ ) of a phage suspension (titer of $10^{7} \mathrm{PFU} / \mathrm{mL}$ ) onto LB overlays that were seeded with bacteria of interest. EOP values were determined for sensitive strains by dividing phage titer on target bacterium by phage titer on host bacterium. Bacterial strains used in host range study are listed in Supplementary Information 1, Table S1, and Supplementary Information 6, Table S1.

One-step-growth curve assay was performed in a similar manner as previously described [56,57]. Phage host strains were grown to an OD600 of 0.20-0.23 (approx. $1 \times 10^{8} \mathrm{CFU} / \mathrm{mL}$ ), followed by centrifugation of $2 \mathrm{~mL}$ in a microfuge to pellet bacteria. The pellet was resuspended in $1 \mathrm{~mL}$ of phage suspension to yield an approx. MOI of $5 \times 10^{-4}$ following incubation at $25^{\circ} \mathrm{C}$ for one minute. This was then centrifuged to pellet bacteria and the supernatant was removed, thus separating bound from unbound phages. The bacterial pellet with bound phage was then resuspended in $10 \mathrm{~mL}$ of LB and incubated aerobically in a water bath at $25^{\circ} \mathrm{C}$ with agitation at $60 \mathrm{rpm}$. At five-minute intervals, aliquots were removed to measure phage titer by the overlay method. Based on the number of PFU $/ \mathrm{mL}$, the latent period and the burst size were determined, by dividing the average $\mathrm{PFU} / \mathrm{mL}$ of the latent period by the average $\mathrm{PFU} / \mathrm{mL}$ of the last four time points of the experiment.

Phage stability was tested by incubating phage suspension of $10^{6} \mathrm{PFU} / \mathrm{mL}$ in SM buffer $(50 \mathrm{mM}$ Tris. $\mathrm{HCl} \mathrm{pH} \mathrm{7.5,} 100 \mathrm{mM} \mathrm{NaCl}, 8 \mathrm{mM} \mathrm{MgSO}_{4}$ ) at different temperatures for one hour and incubating phage suspension in $\mathrm{pH}$ buffer ranging from 2 to $12(10 \mathrm{mM}$ trisodium citrate, $10 \mathrm{mM}$ boric acid, and $150 \mathrm{mM} \mathrm{KCl}$, adjusted with $\mathrm{NaOH}$ or $\mathrm{HCl}$ ) for $24 \mathrm{~h}$ [14].

\subsection{CsCl Gradient Purification}

Isopycnic centrifugation through $\mathrm{CsCl}$ gradients was performed, as previously described [58], with a number of modifications. A high titer phage lysate $\left(>1 \times 10^{9} \mathrm{PFU} / \mathrm{mL}\right)$, was precipitated using polyethylene glycol $(15 \% w / v$ PEG8000, $1 \mathrm{M} \mathrm{NaCl})$ at $4{ }^{\circ} \mathrm{C}$ overnight and centrifuged, after which the pellet was resuspended in TMN buffer $\left(10 \mathrm{mM}\right.$ Tris- $\mathrm{HCl} \mathrm{pH} 7.4,10 \mathrm{mM} \mathrm{MgSO}{ }_{4} \cdot 7 \mathrm{H}_{2} \mathrm{O}$, $0.5 \mathrm{M} \mathrm{NaCl}$ ), and where necessary a chloroform phase separation step (1:1) was conducted to remove debris. The resulting phage preparation was placed onto a $\mathrm{CsCl}$ step gradient composed of 1.3, 1.5, and $1.7 \mathrm{~g} / \mathrm{mL}$ layers and spun in a 100 Ti rotor (Beckman Coulter, Brea, CA, USA) at 200,480 $\mathrm{g}$ for $3 \mathrm{~h}$ 
at $4{ }^{\circ} \mathrm{C}$. Resulting phage bands were collected and subjected to dialysis with two changes of Tris- $\mathrm{HCl}$ buffer $(10 \mathrm{mM}, \mathrm{pH} 7.5)$ at $4{ }^{\circ} \mathrm{C}$.

\subsection{Transmission Electron Microscopy}

Phages were negatively stained on freshly prepared ultra-thin carbon films with $2 \%(w / v)$ uranyl acetate and with $1 \%$ phosphotungstic acid, as described in detail earlier [59]. Micrographs were taken using a Tecnai 10 transmission electron microscope (FEI Thermo Fisher, Eindhoven, The Netherlands) at an acceleration voltage of $80 \mathrm{kV}$ with a MegaView G2 CCD-camera (EMSIS, Muenster, Germany). Measurements of phage dimensions were calculated using samples that were stained with uranyl acetate (head sizes) or with phosphotungstic acid (all other dimensions).

\subsection{DNA Isolation, Restriction and Sequencing}

DNA extraction was performed as previously described [60]. CsCl purified phage particles were treated with DNase and RNase, followed by treatment with 10\% SDS and proteinase $\mathrm{K}$ followed by DNA extraction with phenol: chloroform: isoamyl alcohol (25:24:1 $v / v)$ and chloroform: isoamyl alcohol $(24: 1 v / v)$. DNA samples were digested with BamHI and ClaI, according to manufacturer's protocols (New England BioLabs, Ipswich, MA, USA). The digested DNA was analyzed by agarose gel electrophoresis.

Prior to sequencing, DNA quality and quantity were estimated using both a Nanodrop (ND-1000, Thermo Fisher, Waltham, MA, USA) and by visualization after agarose gel electrophoresis. Genomic sequencing was outsourced to the Centre for Genomic Research at the University of Liverpool, Liverpool, UK. Illumina MiSeq system (Illumina, San Diego, CA, USA), with a TruSeq DNA Nano LT library sample preparation kit for library preparation. Library quality was assessed using the Agilent Bioanalyzer (Agilent Technologies, Santa Clara, CA, USA) and Qubit measurements prior to being sequenced with paired-end reads of $2 \times 250 \mathrm{bp}$. Reads were assembled using Spades genome assembler v.3.10 (St. Petersburg, Russia).

\subsection{Bioinformatic Analysis}

ORFs of CB1, CB3, and CB4 were predicted with GLIMMER [61] and GenmarkS [62]. Further analysis of predicted ORF gene products was conducted with BLASTP (http:/ /blast.ncbi. nlm.nih.gov/Blast.cgi?PAGE=Proteins), Pfam (http://pfam.xfam.org/search\#tabview=tab1; [63]), InterProScan (https://www.ncbi.nlm.nih.gov/pmc/articles/PMC3998142/; [64]), and HHpred (https: // toolkit.tuebingen.mpg.de/\#/tools/hhpred; [65]). With the detection of ORFs with transmembrane domains and lipoprotein cleavage signal being identified with the use of TMHMM v.2 (http:/ /www. cbs.dtu.dk/services/TMHMM/; [66]) and LipoP v.1 (http:/ /www.cbs.dtu.dk/services/LipoP/; [67]), respectively. The molecular weights of the predicted ORFs were estimated using the batch protein molecular weight determination of the sequence manipulation suite (http:/ / www.bioinformatics. org/sms2/protein_mw.html). The presence of transfer RNA genes was investigated with the use of tRNAscan-SE (http://lowelab.ucsc.edu/tRNAscan-SE/; [68]) and ARAGORN (http://130.235. 46.10/ARAGORN/; [69]). Potential Rho-independent terminators in were identified using ARNold (http:/ / rna.igmors.u-psud.fr/toolbox/arnold; [70]) with Mfold QuikFold (http:/ / unafold.rna.albany. edu/?q=DINAMelt/Quickfold; [71]) using RNA energy rules 3.0 to verify predictions, with putative single-stranded hairpin promoters identification being assisted with Mfold QuikFold using DNA energy rules.

\subsection{Comparative Genomics}

The linear genomic comparison maps of CB1 and other N4-like phages were created with the use of either BLASTN or TBLASTX to determine genome homology and it was visualized with Easyfig [72]. Artemis Comparison Tool (ACT) was used for the identification of feature variations between the genomes of the CB1-like phages, with homology being assessed with BLASTN [73]. Phylogenetic 
analysis employed the use of the DNA polymerase and vRNA polymerase proteins of 38 N4-like phages as well as those of CB1-like phages (Supplementary Information 6, Table S2) using MEGA7 [74], involving the use of MUSCLE for sequence alignment [75], with the construction of phylograms using the maximum likelihood (ML) method that was based on the Jones-Thornton-Taylor model [76], with the robustness of the trees being assessed with bootstrapping (1000). The heat map comparing the genomes of 38 N4-like phages and CB1-like phages was generated using Gegenees, using accurate parameters (fragment length: $200 \mathrm{bp}$; step size: $100 \mathrm{bp}$; threshold: 0\%) [77].

\subsection{Phage CB1 Virion ESI-MS/MS Proteome Analysis}

Phage capsid proteins were extracted from high titer $\mathrm{CsCl}$ purified phage $\left(>1 \times 10^{9} \mathrm{PFU} / \mathrm{mL}\right)$ using chloroform:methanol extraction $(1: 1: 0.75, v / v / v)$. The resulting protein pellet was resuspended in loading buffer (1\% SDS, 6\% sucrose, $100 \mathrm{mM}$ dithiothreitol, $10 \mathrm{mM}$ Tris $\mathrm{pH} 6.8,0.0625 \% \mathrm{w} / \mathrm{v}$ bromophenol blue) and heated to $95{ }^{\circ} \mathrm{C}$ for $5 \mathrm{~min}$ to resuspend the pellet. This was subsequently loaded onto a $12 \%$ SDS-PAGE gel, after which gel electrophoresis was conducted. The resulting gel was then stained using Gelcode ${ }^{\mathrm{TM}}$ Blue Safe Protein Stain (Thermo Fisher) to visualize virion proteins. Gel fragments were extracted and subjected to tyrosination, which were analyzed using ESI-MS/MS exactly, as described previously [78].

\subsection{Biocontrol Assays to Determine Biocontrol Potential CB1, CB3 and CB4 Mixture}

The potato whole tuber rot assay was used to assess the potential of a phage mixture comprised of phages CB1, CB3, and CB4 to prevent infection of potato tissue by P. atrosepticum and was conducted in a similar manner, as previously described [15]. The phage mixture was made by adding an equal number of phages to a total titer approx. $1 \times 10^{7} \mathrm{PFU} / \mathrm{mL}$ to SM buffer. P. atrosepticum strains, DSM 18077 and DSM 30186, were resuspended in deionized water with cell numbers of approx. $1 \times 10^{7} \mathrm{CFU} / \mathrm{mL}$ and mixed in equal quantities. Ware potato tubers were obtained at a local supermarket, these were first washed with tap water, then surface sterilized for $10 \mathrm{~min}$ in $70 \%$ isopropanol, then again washed with tap water, and allowed to dry on tissue paper at room temperature.

Whole tuber assay involved tubers being incised at the rose end (opposite the stolon end) to remove a $0.5 \mathrm{~cm}$ transverse slice. To which, $100 \mu \mathrm{L}$ of either bacteria or water was added, left to absorb and then followed with the addition of $100 \mu \mathrm{L}$ of SM buffer or phage mixture. These were then allowed $30 \mathrm{~min}$ to sit at room temperature before the detached potato slices were reattached using sterile toothpicks to tubers. Tubers were then incubated or $72 \mathrm{~h}$ at $25^{\circ} \mathrm{C}$ in a humid box. To assess the protective effect of the phage mixture, the weight of rotten tissue was determined for each tuber.

\subsection{Statistical Analyses of Data}

Figure 7 was generated with Excel. Statistical analysis was preformed with IBM SPSS Software v. 24, (Armonk, NY, USA). Normality of data was assessed with the Shapiro-Wilks test at a significance level of 0.05 . Non-parametric tests were chosen for data not normally distributed. Comparison of weight of soft rot tissue of infected potatoes, phage treated and untreated, were performed with the Mann-Withney U test.

\subsection{Accession Number}

The genome sequences of phages CB1, CB3, CB4 were submitted to GenBank under accession numbers KY514264, KY514265, and KY549659, respectively.

Supplementary Materials: The following are available online at http://www.mdpi.com/1424-8247/11/2/45/s1, Supplementary information 1 Figure S1: One-step-growth growth analysis of phage CB1 infection of P. atrosepticum strain DSM18077, phage CB3 infection of P. atrosepticum strain DSM30186 and phage CB4 infection of P. atrosepticum strain DSM30186, Supplementary information 1 Figure S2: Stability of Pectobacterium phages CB1, CB3 and CB4 to various $\mathrm{pH}$ values upon $24 \mathrm{~h}$ of exposure, Supplementary information 1 Figure S3. Stability of Pectobacterium phages CB1, CB3 and CB4 to various temperatures upon one-hour exposure, Supplementary information 1 
Figure S4: Genomic DNA of Pectobacterium phage CB1, which had been digested with restriction enzyme ClaI, Supplementary information 1 Figure S5: Genomic DNA of Pectobacterium phage CB3, which had been digested with restriction enzyme ClaI, Supplementary information 1 Figure S6: Genomic DNA of Pectobacterium phage CB4, which had been digested with restriction enzyme ClaI, Supplementary information 1 Figure S7: Pictures of the typical observed outcomes for the tuber rot assays, Supplementary information 1 Table S1. Results of physiological, biochemical, Pectobacterium genus specific and Pectobacterium atrosepticum and Pectobacterium carotovorum subsp. carotovorum species specific PCRs and MALDI-TOF mass spectrometry on isolates obtained from potato stem samples symptomatic for blackleg from farms in Co. Cork, Ireland, Supplementary information 1, Table S2. Identified ORFs and tRNA gene variations between the genomes of Pectobacterium phages CB1, CB3 and CB4, Supplementary information 1, Table S3. Homologs of the eighteen core proteins described by Li et al. 2016 found present in the genomes of Pectobacterium phages CB1, CB3 and CB4, Supplementary information 1, Table S4. Putative single-stranded hairpin promoters predicted in the genomes of Pectobacterium phages CB1, CB3 and CB4 identified assisted with QuikFold, Supplementary information 1, Table S5. High $\Delta \mathrm{G}$ rho-independent terminators predicted in the genome Pectobacterium phage CB1 identified using ARNold and QuikFold, Supplementary information 1, Table S6. High $\Delta \mathrm{G}$ rho-independent terminators predicted in the genome Pectobacterium phage CB3 identified using ARNold and QuikFold, Supplementary information 1, Table S7. High $\Delta G$ rho-independent terminators predicted in the genome Pectobacterium phage CB4 identified using ARNold and QuikFold. Supplementary information 1, Table S8. Shared high $\triangle \mathrm{G}$ putative rho-independent terminators among Pectobacterium phages CB1, CB3 and CB4. Supplementary information 2, Table S1. Genome annotation of Pectobacterium phage CB1, Supplementary information 3, Table S1. Genome annotation of Pectobacterium phage CB3, Supplementary information 4, Table S1. Genome annotation of Pectobacterium phage CB4, Supplementary information 5, Table S1. Output from ESI-MS/MS from analysis of Pectobacterium phage CB1 virion proteins, Supplementary information 6, Table S1. Bacteria strains used in the Isolation and the testing of host range of Pectobacterium phages CB1, CB3 and CB4, Supplementary information 6, Table S2. Table S2. Genbank details of N4-like phages used in phylograms and Gegenees analysis.

Author Contributions: C.B. conducted the majority of work and wrote the manuscript, H.H. prepared phage virion proteins for MS and analyzed resulting output, A.L. assembled phage genomes from sequence reads, H.N. and C.F. produced TEM imagines of phages and critically read the manuscript, J.-P.N. provided resources for MS, R.L. provided bacterial strains for host range study and critically read the manuscript, J.O. critically read the manuscript and A.C. conceived, funded and guided the study.

Acknowledgments: This work was supported by Science Foundation Ireland, project reference 12/R1/2335. H.H. and R.L. are supported by the GOA project 'Phage Biosystems' of the KU Leuven. Angela Back (MRI Kiel) is acknowledged for her technical assistance with transmission electron microscopy. We would also like to thank the West Cork farmers who provided plant and soil samples for the study.

Conflicts of Interest: The authors declare no conflict of interest.

\section{References}

1. Toth, I.K.; van der Wolf, J.M.; Saddler, G.; Lojkowska, E.; Hélias, V.; Pirhonen, M.; Tsror Lahkim, L.; Elphinstone, J.G. Dickeya species: An emerging problem for potato production in Europe. Plant Pathol. 2011, 60, 385-399. [CrossRef]

2. Pérombelon, M.C.M. Potato diseases caused by soft rot erwinias: An overview of pathogenesis. Plant Pathol. 2002, 51, 1-12. [CrossRef]

3. Mansfield, J.; Genin, S.; Magori, S.; Citovsky, V.; Sriariyanum, M.; Ronald, P.; Dow, M.A.X.; Verdier, V.; Beer, S.V.; Machado, M.A.; et al. Top 10 plant pathogenic bacteria in molecular plant pathology. Mol. Plant Pathol. 2012, 13, 614-629. [CrossRef] [PubMed]

4. Waleron, M.; Waleron, K.; Lojkowska, E. Occurrence of Pectobacterium wasabiae in potato field samples. Eur. J. Plant Pathol. 2013, 137, 149-158. [CrossRef]

5. Van der Wolf, J.M.; de Haan, E.G.; Kastelein, P.; Krijger, M.; de Haas, B.H.; Velvis, H.; Mendes, O.; Kooman-Gersmann, M.; van der Zouwen, P.S. Virulence of Pectobacterium carotovorum subsp. brasiliense on potato compared with that of other Pectobacterium and Dickeya species under climatic conditions prevailing in the Netherlands. Plant Pathol. 2017, 66, 571-583. [CrossRef]

6. Khayi, S.; Cigna, J.; Chong, T.M.; Quêtu-Laurent, A.; Chan, K.-G.; Hélias, V.; Faure, D. Transfer of the potato plant isolates of Pectobacterium wasabiae to Pectobacterium parmentieri sp. nov. Int. J. Syst. Evol. Microbiol. 2016, 66, 5379-5383. [CrossRef] [PubMed]

7. Toth, I.K.; Bell, K.S.; Holeva, M.C.; Birch, P.R.J. Soft rot erwiniae: From genes to genomes. Mol. Plant Pathol. 2003, 4, 17-30. [CrossRef] [PubMed]

8. Czajkowski, R.; Pérombelon, M.C.M.; van Veen, J.A.; van der Wolf, J.M. Control of blackleg and tuber soft rot of potato caused by Pectobacterium and Dickeya species: A review. Plant Pathol. 2011, 60, 999-1013. [CrossRef] 
9. De Boer, S.H. Blackleg of potato. Plant Heal. Instr. 2004. [CrossRef]

10. Buttimer, C.; McAuliffe, O.; Ross, R.P.P.; Hill, C.; O’Mahony, J.; Coffey, A.; O’Mahony, J.; Coffey, A. Bacteriophages and bacterial plant diseases. Front. Microbiol. 2017, 8, 34. [CrossRef] [PubMed]

11. Frampton, R.A.; Pitman, A.R.; Fineran, P.C. Advances in bacteriophage-mediated control of plant pathogens. Int. J. Microbiol. 2012, 2012, 326452. [CrossRef] [PubMed]

12. Czajkowski, R. Bacteriophages of soft rot Enterobacteriaceae-A minireview. FEMS Microbiol. Lett. 2016, 363, fnv230. [CrossRef] [PubMed]

13. Smolarska, A.; Rabalski, L.; Narajczyk, M.; Czajkowski, R. Isolation and phenotypic and morphological characterization of the first Podoviridae lytic bacteriophages $\varphi \mathrm{A} 38$ and $\varphi \mathrm{A} 41$ infecting Pectobacterium parmentieri (former Pectobacterium wasabiae). Eur. J. Plant Pathol. 2018, 150, 413-425. [CrossRef]

14. Adriaenssens, E.M.; Van Vaerenbergh, J.; Vandenheuvel, D.; Dunon, V.; Ceyssens, P.-J.; De Proft, M.; Kropinski, A.M.; Noben, J.-P.; Maes, M.; Lavigne, R. T4-related bacteriophage LIMEstone isolates for the control of soft rot on potato caused by 'Dickeya solani'. PLoS ONE 2012, 7, e33227. [CrossRef] [PubMed]

15. Czajkowski, R.; Ozymko, Z.; de Jager, V.; Siwinska, J.; Smolarska, A.; Ossowicki, A.; Narajczyk, M.; Lojkowska, E. Genomic, proteomic and morphological characterization of two novel broad host lytic bacteriophages $\Phi$ PD10.3 and $\Phi$ PD23.1 infecting pectinolytic Pectobacterium spp. and Dickeya spp. PLoS ONE 2015, 10, e0119812. [CrossRef] [PubMed]

16. Ravensdale, M.; Blom, T.J.; Gracia-Garza, J.A.; Svircev, A.M.; Smith, R.J. Bacteriophages and the control of Erwinia carotovora subsp. carotovora. Can. J. Plant Pathol. 2010, 29, 121-130. [CrossRef]

17. Lim, J.-A.; Jee, S.; Lee, D.H.; Roh, E.; Jung, K.; Oh, C.; Heu, S. Biocontrol of Pectobacterium carotovorum subsp. carotovorum using bacteriophage PP1. J. Microbiol. Biotechnol. 2013, 23, 1147-1153. [CrossRef] [PubMed]

18. Molina, A.M.; Pesce, A.; Shito, G.C. Un nuovo batteriofago attivo sul ceppo K12 di E. coli. I. Caratteristiche biologiche. Boll. Inst. Sieroter. 1965, 44, 329-337.

19. Glucksmann, M.A.; Markiewicz, P.; Malone, C.; Rothman-Denes, L.B. Specific sequences and a hairpin structure in the template strand are required for N4 virion RNA polymerase promoter recognition. Cell 1992, 70, 491-500. [CrossRef]

20. Adriaenssens, E.M.; C Clokie, M.R.; Sullivan, M.B.; Gillis, A.; Jens Kuhn, B.H.; Kropinski, A.M. Taxonomy of prokaryotic viruses: 2016 update from the ICTV bacterial and archaeal viruses subcommittee. Arch. Virol. 2017, 162, 1153-1157. [CrossRef] [PubMed]

21. Wittmann, J.; Klumpp, J.; Moreno Switt, A.I.; Yagubi, A.; Ackermann, H.-W.; Wiedmann, M.; Svircev, A.; Nash, J.H.E.; Kropinski, A.M. Taxonomic reassessment of N4-like viruses using comparative genomics and proteomics suggests a new subfamily-“Enquartavirinae”. Arch. Virol. 2015, 160, 3053-3062. [CrossRef] [PubMed]

22. Wittmann, J.; Kropinski, A.M.; Adriaenssens, E.M.; Ackermann, H.-W.; Lavigne, R.; Kuhn, J.H.; Uchiyama, J. To Create a New Genus, Luz7virus, including 2 (Two) New Species within the Family Podoviridae. Available online: https:/ / talk.ictvonline.org/ICTV/proposals/2016.024a-dB.A.v2.Luz7virus.pdf (accessed on 22 January 2018).

23. Wittmann, J.; Grose, J.H.; Yagubi, A.I.; Svircev, A.M.; Kropinski, A.M. To Create a New Genus, Ea92virus, Including 2 (Two) New Species within the Family Podoviridae. Available online: https://talk.ictvonline. org/files/ictv_official_taxonomy_updates_since_the_8th_report/m/prokaryote-official/ 6772 (accessed on 22 January 2018).

24. Ackermann, H.W. Frequency of morphological phage descriptions in the year 2000. Brief review. Arch. Virol. 2001, 146, 843-857. [CrossRef] [PubMed]

25. Kropinski, A.M.; Prangishvili, D.; Lavigne, R. Position paper: The creation of a rational scheme for the nomenclature of viruses of Bacteria and Archaea. Environ. Microbiol. 2009, 11, 2775-2777. [CrossRef] [PubMed]

26. Fouts, D.E.; Klumpp, J.; Bishop-Lilly, K.A.; Rajavel, M.; Willner, K.M.; Butani, A.; Henry, M.; Biswas, B.; Li, M.; Albert, M.; et al. Whole genome sequencing and comparative genomic analyses of two Vibrio cholerae O139 Bengal-specific Podoviruses to other N4-like phages reveal extensive genetic diversity. Virol. J. 2013, 10, 165. [CrossRef] [PubMed]

27. Li, S.; Fan, H.; An, X.; Fan, H.; Jiang, H.; Chen, Y.; Tong, Y. Scrutinizing virus genome termini by high-throughput sequencing. PLoS ONE 2014, 9, e85806. [CrossRef] [PubMed] 
28. Ohmori, H.; Haynes, L.L.; Rothman-Denes, L.B. Structure of the ends of the coliphage N4 genome. J. Mol. Biol. 1988, 202, 1-10. [CrossRef]

29. Bell, K.S.; Sebaihia, M.; Pritchard, L.; Holden, M.T.G.; Hyman, L.J.; Holeva, M.C.; Thomson, N.R.; Bentley, S.D.; Churcher, L.J.C.; Mungall, K.; et al. Genome sequence of the enterobacterial phytopathogen Erwinia carotovora subsp. atroseptica and characterization of virulence factors. Proc. Natl. Acad. Sci. USA 2004, 101, 11105-11110. [CrossRef] [PubMed]

30. Nikolaichik, Y.; Gorshkov, V.; Gogolev, Y.; Valentovich, L.; Evtushenkov, A. Genome sequence of Pectobacterium atrosepticum strain 21A. Genome Announc. 2014, 2. [CrossRef] [PubMed]

31. Adriaenssens, E.M.; Rodney Brister, J. How to name and classify your phage: An informal guide. Viruses 2017, 9, 70. [CrossRef] [PubMed]

32. Li, B.; Zhang, S.; Long, L.; Huang, S. Characterization and complete genome sequences of three N4-Like Roseobacter phages isolated from the south China sea. Curr. Microbiol. 2016, 73, 409-418. [CrossRef] [PubMed]

33. Ceyssens, P.-J.; Brabban, A.; Rogge, L.; Lewis, M.S.; Pickard, D.; Goulding, D.; Dougan, G.; Noben, J.-P.; Kropinski, A.; Kutter, E.; et al. Molecular and physiological analysis of three Pseudomonas aeruginosa phages belonging to the "N4-like viruses". Virology 2010, 405, 26-30. [CrossRef] [PubMed]

34. Kulikov, E.; Kropinski, A.M.; Golomidova, A.; Lingohr, E.; Govorun, V.; Serebryakova, M.; Prokhorov, N.; Letarova, M.; Manykin, A.; Strotskaya, A.; et al. Isolation and characterization of a novel indigenous intestinal N4-related coliphage vB_EcoP_G7C. Virology 2012, 426, 93-99. [CrossRef] [PubMed]

35. Carter, R.H.; Demidenko, A.A.; Hattingh-Willis, S.; Rothman-Denes, L.B. Phage N4 RNA polymerase II recruitment to DNA by a single-stranded DNA-binding protein. Genes Dev. 2003, 17, 2334-2345. [CrossRef] [PubMed]

36. Choi, M.; Miller, A.; Cho, N.Y.; Rothman-Denes, L.B. Identification, cloning, and characterization of the bacteriophage N4 gene encoding the single-stranded DNA-binding protein. A protein required for phage replication, recombination, and late transcription. J. Biol. Chem. 1995, 270, 22541-22547. [CrossRef] [PubMed]

37. Murphy, J.; Mahony, J.; Ainsworth, S.; Nauta, A.; van Sinderen, D. Bacteriophage orphan DNA methyltransferases: Insights from their bacterial origin, function, and occurrence. Appl. Environ. Microbiol. 2013, 79, 7547-7555. [CrossRef] [PubMed]

38. Stojković, E.A.; Rothman-Denes, L.B. Coliphage N4 N-acetylmuramidase defines a new family of murein hydrolases. J. Mol. Biol. 2007, 366, 406-419. [CrossRef] [PubMed]

39. Savva, C.G.; Dewey, J.S.; Moussa, S.H.; To, K.H.; Holzenburg, A.; Young, R. Stable micron-scale holes are a general feature of canonical holins. Mol. Microbiol. 2014, 91, 57-65. [CrossRef] [PubMed]

40. Young, R. Phage lysis: Three steps, three choices, one outcome. J. Microbiol. 2014, 52, 243-258. [CrossRef] [PubMed]

41. Choi, K.H.; McPartland, J.; Kaganman, I.; Bowman, V.D.; Rothman-Denes, L.B.; Rossmann, M.G. Insight into DNA and protein transport in double-stranded DNA viruses: The structure of bacteriophage N4. J. Mol. Biol. 2008, 378, 726-736. [CrossRef] [PubMed]

42. Hardies, S.C.; Thomas, J.A.; Black, L.; Weintraub, S.T.; Hwang, C.Y.; Cho, B.C. Identification of structural and morphogenesis genes of Pseudoalteromonas phage $\varphi$ RIO-1 and placement within the evolutionary history of Podoviridae. Virology 2016, 489, 116-127. [CrossRef] [PubMed]

43. Prokhorov, N.S.; Riccio, C.; Zdorovenko, E.L.; Shneider, M.M.; Browning, C.; Knirel, Y.A.; Leiman, P.G.; Letarov, A.V. Function of bacteriophage G7C esterase tailspike in host cell adsorption. Mol. Microbiol. 2017, 105, 385-398. [CrossRef] [PubMed]

44. Bord Bia the Irish Food Board Potato Industry Welcomes $€ 1$ Million Marketing Boost. Available online: https: / / www.bordbia.ie/corporate/press/2015/pages/Potatoindustry1millionmarketingboost.aspx (accessed on 22 January 2018).

45. Shigehisa, R.; Uchiyama, J.; Kato, S.; Takemura-Uchiyama, I.; Yamaguchi, K.; Miyata, R.; Ujihara, T.; Sakaguchi, Y.; Okamoto, N.; Shimakura, H.; et al. Characterization of Pseudomonas aeruginosa phage KPP21 belonging to family Podoviridae genus N4-like viruses isolated in Japan. Microbiol. Immunol. 2016, 60, 64-67. [CrossRef] [PubMed]

46. Katharios, P.; Kalatzis, P.G.; Kokkari, C.; Sarropoulou, E.; Middelboe, M. Isolation and characterization of a N4-like lytic bacteriophage infecting Vibrio splendidus, a pathogen of fish and bivalves. PLoS ONE 2017, 12, e0190083. [CrossRef] [PubMed] 
47. Chan, J.Z.-M.; Millard, A.D.; Mann, N.H.; Schäfer, H. Comparative genomics defines the core genome of the growing N4-like phage genus and identifies N4-like Roseophage specific genes. Front. Microbiol. 2014, 5, 506. [CrossRef] [PubMed]

48. García, P.; Martínez, B.; Obeso, J.M.; Rodríguez, A. Bacteriophages and their application in food safety. Lett. Appl. Microbiol. 2008, 47, 479-485. [CrossRef] [PubMed]

49. Chan, B.K.; Abedon, S.T.; Loc-Carrillo, C. Phage cocktails and the future of phage therapy. Future Microbiol. 2013, 8, 769-783. [CrossRef] [PubMed]

50. Hélias, V.; Hamon, P.; Huchet, E.; Wolf, J.V.D.; Andrivon, D. Two new effective semiselective crystal violet pectate media for isolation of Pectobacterium and Dickeya. Plant Pathol. 2012, 61, 339-345. [CrossRef]

51. Perombelon, M.C.M.; Van Der Wolf, J.M. Methods for the Detection and Quantification of Erwinia carotovora subsp. atroseptica (Pectobacterium carotovorum subsp. atrosepticum) on Potatoes: A Laboratory Manual; Scottish Crop Research Institute Occasional Publication: Dundee, UK, 2002.

52. Darrasse, A.; Priou, S.; Kotoujansky, A.; Bertheau, Y. PCR and restriction fragment length polymorphism of a pel gene as a tool to identify Erwinia carotovora in relation to potato diseases. Appl. Environ. Microbiol. 1994, 60, 1437-1443. [PubMed]

53. De Boer, S.H.; Ward, L.J. PCR detection of Erwinia carotovora subsp atroseptica associated with potato tissue. Phytopathology 1995, 85, 854-858. [CrossRef]

54. Kang, H.W.; Kwon, S.W.; Go, S.J. PCR-based specific and sensitive detection of Pectobacterium carotovorum ssp. carotovorum by primers generated from a URP-PCR fingerprinting-derived polymorphic band. Plant Pathol. 2003, 52, 127-133. [CrossRef]

55. Sambrook, J.; Russell, D.W. Picking bacteriophage Lamda plaques. In Molecular Cloning: A Laboratory Manual; Cold Spring Harbor Laboratory Press: Cold Spring Harbor, NY, USA, 2001; Volume 1, p. 2.32, ISBN 0879695773.

56. Park, M.; Lee, J.-H.; Shin, H.; Kim, M.; Choi, J.; Kang, D.-H.; Heu, S.; Ryu, S. Characterization and comparative genomic analysis of a novel bacteriophage, SFP10, simultaneously inhibiting both Salmonella enterica and Escherichia coli O157:H7. Appl. Environ. Microbiol. 2012, 78, 58-69. [CrossRef] [PubMed]

57. Yang, H.; Liang, L.; Lin, S.; Jia, S. Isolation and characterization of a virulent bacteriophage AB1 of Acinetobacter baumannii. BMC Microbiol. 2010, 10, 131. [CrossRef] [PubMed]

58. Sambrook, J.; Russell, D.W. Purification of bacteriophage lamda particles by isopycnic centrifugation through CsCl gradients. In Molecular Cloning: A Laboratory Manual; Cold Spring Harbor Laboratory Press: Cold Spring Harbor, NY, USA, 2001; Volume 1, p. 2.47, ISBN 0879695773.

59. Casey, E.; Mahony, J.; O’Connell-Motherway, M.; Bottacini, F.; Cornelissen, A.; Neve, H.; Heller, K.J.; Noben, J.-P.; Dal Bello, F.; van Sinderen, D. Molecular characterization of three Lactobacillus delbrueckii subsp. bulgaricus phages. Appl. Environ. Microbiol. 2014, 80, 5623-5635. [CrossRef] [PubMed]

60. Pickard, D.J.J. Preparation of bacteriophage lysates and pure DNA. Methods Mol. Biol. 2009, 502, 3-9. [CrossRef] [PubMed]

61. Delcher, A.L.; Harmon, D.; Kasif, S.; White, O.; Salzberg, S.L. Improved microbial gene identification with GLIMMER. Nucleic Acids Res. 1999, 27, 4636-4641. [CrossRef] [PubMed]

62. Besemer, J.; Lomsadze, A.; Borodovsky, M. GeneMarkS: A self-training method for prediction of gene starts in microbial genomes. Implications for finding sequence motifs in regulatory regions. Nucleic Acids Res. 2001, 29, 2607-2618. [CrossRef] [PubMed]

63. Finn, R.D.; Coggill, P.; Eberhardt, R.Y.; Eddy, S.R.; Mistry, J.; Mitchell, A.L.; Potter, S.C.; Punta, M.; Qureshi, M.; Sangrador-Vegas, A.; et al. The Pfam protein families database: Towards a more sustainable future. Nucleic Acids Res. 2015, 44, D279-D285. [CrossRef] [PubMed]

64. Mitchell, A.; Chang, H.-Y.; Daugherty, L.; Fraser, M.; Hunter, S.; Lopez, R.; McAnulla, C.; McMenamin, C.; Nuka, G.; Pesseat, S.; et al. The InterPro protein families database: The classification resource after 15 years. Nucleic Acids Res. 2014, 43, D213-D221. [CrossRef] [PubMed]

65. Söding, J.; Biegert, A.; Lupas, A.N. The HHpred interactive server for protein homology detection and structure prediction. Nucleic Acids Res. 2005, 33, W244-W248. [CrossRef] [PubMed]

66. Krogh, A.; Larsson, B.; von Heijne, G.; Sonnhammer, E.L. Predicting transmembrane protein topology with a hidden markov model: Application to complete genomes. J. Mol. Biol. 2001, 305, 567-580. [CrossRef] [PubMed] 
67. Juncker, A.S.; Willenbrock, H.; von Heijne, G.; Brunak, S.; Nielsen, H.; Krogh, A. Prediction of lipoprotein signal peptides in Gram-negative bacteria. Protein Sci. 2003, 12, 1652-1662. [CrossRef] [PubMed]

68. Lowe, T.M.; Eddy, S.R. tRNAscan-SE: A program for improved detection of transfer RNA genes in genomic sequence. Nucleic Acids Res. 1997, 25, 955-964. [CrossRef] [PubMed]

69. Laslett, D.; Canback, B. ARAGORN, a program to detect tRNA genes and tmRNA genes in nucleotide sequences. Nucleic Acids Res. 2004, 32, 11-16. [CrossRef] [PubMed]

70. Naville, M.; Ghuillot-Gaudeffroy, A.; Marchais, A.; Gautheret, D. ARNold: A web tool for the prediction of Rho-independent transcription terminators. RNA Biol. 2011, 8, 11-13. [CrossRef] [PubMed]

71. Zuker, M. Mfold web server for nucleic acid folding and hybridization prediction. Nucleic Acids Res. 2003, 31, 3406-3415. [CrossRef] [PubMed]

72. Sullivan, M.J.; Petty, N.K.; Beatson, S.A. Easyfig: A genome comparison visualizer. Bioinformatics 2011, 27, 1009-1010. [CrossRef] [PubMed]

73. Carver, T.J.; Rutherford, K.M.; Berriman, M.; Rajandream, M.-A.; Barrell, B.G.; Parkhill, J. ACT: The Artemis comparison tool. Bioinformatics 2005, 21, 3422-3423. [CrossRef] [PubMed]

74. Kumar, S.; Stecher, G.; Tamura, K. MEGA7: Molecular Evolutionary Genetics Analysis Version 7.0 for Bigger Datasets. Mol. Biol. Evol. 2016, 33, 1870-1874. [CrossRef] [PubMed]

75. Edgar, R.C. MUSCLE: Multiple sequence alignment with high accuracy and high throughput. Nucleic Acids Res. 2004, 32, 1792-1797. [CrossRef] [PubMed]

76. Jones, D.T.; Taylor, W.R.; Thornton, J.M. The rapid generation of mutation data matrices from protein sequences. Bioinformatics 1992, 8, 275-282. [CrossRef]

77. Ågren, J.; Sundström, A.; Håfström, T.; Segerman, B. Gegenees: Fragmented alignment of multiple genomes for determining phylogenomic distances and genetic signatures unique for specified target groups. PLoS ONE 2012, 7, e39107. [CrossRef] [PubMed]

78. Van den Bossche, A.; Ceyssens, P.-J.; De Smet, J.; Hendrix, H.; Bellon, H.; Leimer, N.; Wagemans, J.; Delattre, A.-S.; Cenens, W.; Aertsen, A.; et al. Systematic identification of hypothetical bacteriophage proteins targeting key protein complexes of Pseudomonas aeruginosa. J. Proteome Res. 2014, 13, 4446-4456. [CrossRef] [PubMed]

(C) 2018 by the authors. Licensee MDPI, Basel, Switzerland. This article is an open access article distributed under the terms and conditions of the Creative Commons Attribution (CC BY) license (http:/ / creativecommons.org/licenses/by/4.0/). 